\title{
SIR HENRY WELLCOME'S MUSEUM FOR THE SCIENCE OF HISTORY
}

by

\author{
GHISLAINE M. SKINNER*
}

"The study of anthropology comprehends all human activities including the healing art"1

\section{I}

The collection of artefacts amassed by Sir Henry Solomon Wellcome (1853-1936) known, since 1913, as his Historical Medical Museum and, since its transfer to the Science Museum in 1977, as the Wellcome Museum of the History of Medicine, has frequently aroused amazement because of its enormous size and range. By the early 1930s, Wellcome's collection was five times larger than that of the Louvre and, during the 1920s, its annual expenditure on acquisitions exceeded that of the British Museum. ${ }^{2}$ Despite being known as a historical medical collection, in range it was almost indefinably wide. At the time of Wellcome's death, it included large quantities of, for example, weapons, model ships, bales of fabric, furniture, porcelain, statuary, coins and medals, oriental and western antiquities, objets d'art, potsherds, human remains and "ethnographical" items, in all approximately one million objects. ${ }^{3}$

This paper is an attempt to place Wellcome's activities in context. His collection becomes more comprehensible when considered in the light of the prominence museums were given in archaeology and anthropology from about 1870 , and the

* Ghislaine M. Skinner, MB, BS, MSc, Wellcome Museum of the History of Medicine, The Science Museum, South Kensington, London SW7 2DD.

${ }^{1}$ Henry Wellcome, in Great Britain, Royal Commission on national museums and galleries, 'Oral evidence, memoranda and appendices to the final report', London, HMSO, 1929, p. 10. Hereinafter Evidence.

2 In 1933, the Louvre held 173,000 items. See 'Le plan d'extension et de régroupement méthodique des collections du Musée du Louvre', Bulletin des Musées de France, Paris, 1934. Wellcome's collections filled 12,000 packing-cases at the time of his death in 1936. There were also many hundreds of free-standing items and, if an average of seventy-five items per case is assumed, the total approaches a million. Expenditure on UK sale room acquisitions alone had reached $£ 60,000$ per annum between 1918 and 1920 . See $P$. Johnston-Saint, 'A brief résumé of the history of the H.M.M. stores and of some of the difficulties encountered in the development of the museum', 23 February 1943, Wellcome Institute Archives, Unclassified material. (See note 10 below.) The British Museum's grant in aid of purchases and acquisitions for 1926-7 was $£ 25,000$. Great Britain Royal Commission on National Museums and Galleries, Interim Report, London, HMSO, 1928, Appendix II.

${ }^{3}$ Numerous accounts stress the diverse nature of the collections in 1936. See, for example, Johnston-Saint, op. cit., note 2 above; and S. H. Daukes, 'The historical medical museum-its future and possibilities', Museums J., 1944, 44: 17-21. One typical consignment of items, unpacked after Wellcome's death, included "lamps, leather items, military equipment, costumes, fabrics, camping equipment, horn and ivory plaques, musical instruments, silver and plated ware”. P. Johnston-Saint, 'H.M.M. Progress Report for January 1938', p. 2. WF:E2:DW. 'Mixed dates, 1912-58'. (See note 10 below.) 


\section{Ghislaine M. Skinner}

resultant concept of the "historical" museum. Wellcome's amateur status and essentially isolated position are not without relevance to the final form that his museum took. His conception of a historical medical museum, formed, it seems, in the 1880 s, showed no evidence of any modification, through contact with related professionals or their opinions, for the rest of his life. In many ways, it was a version of the history of medicine that could have been arrived at only in the closing decades of the nineteenth century. Inconceivable before the 1860 s and unconvincing to some even by the time of the museum's reopening in 1926, it was to prove almost incomprehensible to those responsible for the collection after his death.

The history of collecting and of museums remains in its infancy. David Murray and Alma Wittlin's works, published in 1904 and 1949 respectively, have not been superseded for reference. ${ }^{4}$ Institutional histories of national museums exist, but general historians have made only brief excursions into the nature of collecting even when it impinges on their main field. Social historians have considered it amongst the attributes of the seventeenth- and eighteenth-century virtuosi, whilst historians of science have examined, for example, accounts of the collections of William Hunter and James Hutton for insights into their subjects. ${ }^{5}$ Amongst museum curators themselves, American workers have, since the early years of this century, turned a more critical eye upon their predecessors and their practices than their British or European counterparts. Both the bibliographies of "museology" in existence are of American origin. ${ }^{6}$ Recently, American workers have established the study of "material culture" as a university-based discipline whose historical roots are seen to lie in archaeology, anthropology, folklore and folk life studies, and, latterly, the "social sciences". T. J. Schlereth's comprehensive, interpretative anthology, Material culture studies in America, 1876-1976, sadly has no British counterpart that might provide the background to understanding the activities at the Wellcome Historical Medical Museum from about 1903 to $1934 .^{7}$ Even if the Museum is accepted at its face value as a "medical" museum, there is no good general survey detailing the history of such foundations. ${ }^{8}$

Henry Wellcome himself awaits a full biography. Short accounts of his life and works were commissioned by the Wellcome Foundation in 1953 and the Wellcome

${ }^{4}$ D. Murray, Museums, their history and their use, Glasgow, James MacLehose, 1904, 3 vols. A. Wittlin, The museum. Its history and its tasks in education, London, Routledge \& Kegan Paul, 1949. (Revised as: Museum: in search of a usable future, Cambridge, Mass., MIT Press, 1970.) Two more recent works are Richard D. Altick, The shows of London, Cambridge, Mass., Harvard University Press, 1978, an exhaustive coverage of public exhibitions in the capital from 1600 to 1862; and O. Impey and A. McGregor (editors) The origins of museums, Oxford University Press, 1985, an account of the cabinet collections of Europe to which the origins of modern museums are customarily traced.

5 W.E. Houghton, 'The English virtuoso in the seventeenth century', J. Hist. Ideas, 1942, 3: 51-73, 190-219. C. Helen Brock, 'The happiness of riches', in W. F. Bynum and Roy Porter (editors), William Hunter and the eighteenth-century medical world, Cambridge University Press, 1985. J. Jones, 'The geological collection of James Hutton', Ann. Sci., 1984, 41: 223-244.

$6 \mathrm{~W}$. Clifford, Bibliography of museums and museology, New York, Metropolitan Museum of Art, 1922.

R. C. Smith, A bibliography of museums and museum work, Washington, DC, American Association of Museums, 1928. Murray, op. cit., note 4 above, includes a bibliography of early works.

7 T. J. Schlereth, Material culture studies in America, 1876-1976, Nashville, Tennessee, American Association for State and Local History, 1982.

${ }^{8} \mathrm{~A}$ thesis was written by the second conservator of the Wellcome Historical Medical Museum-L.W.G. Malcolm, 'Medical museums: an historical and bibliographic study', PhD thesis, University of Cambridge, 1933 , but this is very patchy in its coverage. 


\section{Sir Henry Wellcome's museum for the science of history}

Trust in $1980 .^{9}$ The typescript of an unpublished, longer account remains in their archives, together with miscellaneous correspondence files of Wellcome and his museum and library staff, museum and library reports, and such documentation as exists relating to acquisitions. ${ }^{10}$ Wellcome's literary output was small. He seldom committed his thoughts to paper. "My plans exist in my mind like a jig-saw puzzle, and gradually I shall be able to piece it together", he remarked more than once. ${ }^{11}$ For clues to his intentions it is necessary to turn to his handwritten comments on museum reports, or to his occasional public utterances on his collection. Of the museum records, the intermittent series of reports, written for Wellcome if he was abroad by the conservator of the day, perhaps provide the closest insight into the mind of this "curiously lonely" man. ${ }^{12}$ Often typewritten down only one half of the page, the reports were returned with Wellcome's urgent, scribbled comments and directions on the other half, line by line. They reveal just how closely he controlled the venture and in particular the wording of any notice, advertisement, or other publication relating to his museum. His somewhat authoritarian approach to management has frequently been commented on. ${ }^{13}$ It allows one to be reasonably certain that, prior to 1936 , the layout of his museum, the convictions and the sentiments expressed in the usually unsigned texts of museum guides and handbooks, reflect his own ideas.

In brief outline, the course of Wellcome's life and career was as follows: Born in Almond, Wisconsin, in 1853, he was the second son of small-farming parents. His father was also a lay preacher, and later acquired a drug store. When Wellcome was eight years old, the family moved to Garden City, Minnesota, a frontier town still subject to Sioux raids. After an elementary education, Wellcome worked in the family drug store, then for the pharmaceutical company, Poole and Geisinger. He attended

\footnotetext{
${ }^{9}$ Sir Henry Wellcome, A biographical memoir, London, Wellcome Foundation, 1953; and Helen Turner, Henry Wellcome, the man, his collection and his legacy, London, Heinemann Educational Books for the Wellcome Trust, 1980. A biographical account is included in Joseph W. England, 'The Wellcome Historical Medical Museum and its founder', Am. J. Pharm. 1928, 100: 746-757; and in The Wellcome Family of Freeman, Maine, Israel Riggs Bray (1808-1890), Henry Solomon Wellcome (1853-1936), Maine, Phillips, 1939. See also C. M. Wenyon, 'Henry Solomon Wellcome 1853-1936', Obituary Notices of Fellows of the Royal Society of London, January 1938, vol. 2, no. 6 pp. 229-238; and Wellcome's obituary in J. R. African Soc., October 1936, 35, no. 141: 356-367.

${ }_{10}$ Typescript, A. W. Haggis, 'The life and work of Sir Henry Wellcome'. Wellcome Historical Medical Museum, 1942. Archival material relating to the Museum is held by the Wellcome Institute for the History of Medicine and the Wellcome Foundation Ltd, both at 183 Euston Road, London NW1 2BP. The archives are not yet fully catalogued and reference numbers in general refer to files rather than single items. The prefixes W.I: and W.F: denote Wellcome Institute and Wellcome Foundation material respectively, cited by courtesy of the Wellcome Trustees and the Wellcome Foundation Ltd.

11 Interview with George Pearson, Wellcome's deputy and general manager, by A.W. Haggis, 12 December 1940, p. 2, W.I: unclassified material, 'H.S. Wellcome, Biographical Material, Correspondence Reports etc. by A.W.H.'.

${ }^{12}$ Sir Henry Dale, Obituary Tribute, The Times, 1 August 1936. "It may be doubted whether anyone knew him with sufficient intimacy to do more than speculate as to his real feelings and motives", he continued. Dale headed the Wellcome Physiological Research Laboratories prior to World War I and was one of the original Wellcome Trustees. He chaired the Trust from 1938-1960.

${ }^{13}$ Op. cit., note 11 above, p. 1 . See, for example, Pearson's comments. See also a letter written by Wellcome towards the end of his life, to the museum conservator at the time. "I explained to you explicitly what I wanted first of all .... Furthermore, I told you that I would personally supervise and direct the arrangement of these exhibits and decide the methods of display." Quoted in Turner, op. cit., note 9 above, p. 55 .
} 


\section{Ghislaine M. Skinner}

the Chicago College of Pharmacy and subsequently the Philadelphia College of Pharmacy, graduating from there in 1874. There followed a move to London, partnership with Silas Burroughs (1846-95) in 1880, and business success based on the introduction of tabletted medicines to Britain. After Burroughs' early death, Wellcome became sole shareholder of the company, Burroughs Wellcome \& Co. All his business interests were brought together under the Wellcome Foundation Ltd, formed in 1924. Wellcome became a naturalized British subject in 1910 and was knighted in 1932.

It is clear that, if Wellcome's talents and education fitted him for a successful career in the pharmaceutical business, his consuming interests lay elsewhere. His comfortable financial circumstances allowed him to pursue in middle life, either at first hand or through paid employees, subjects in which he had had no formal training, but had long had an interest - archaeology, anthropology, and the history of medicine. On more than one occasion, Wellcome made public reference to "years spent studying" in the British Museum's Library and collections, but these bore no fruit in terms of observational, methodological, or theoretical contributions to his adopted subjects. ${ }^{14} \mathrm{He}$ never lost his amateur status through publication, as did more illustrious predecessors, such as the banker, Henry Christy (1810-64), or the lawyer, Lewis Henry Morgan (1818-81), both wealthy men who turned in middle age to similar interests, but both of whom made considerable contributions to their adopted subjects. ${ }^{15}$ The soldier-turnedarchaeologist, A.H.L.F. Pitt-Rivers (1827-1900), is perhaps the most prominent British example of this phenomenon.

In archaeology and anthropology, amateur, in the sense of unpaid practice, was the rule in late-nineteenth-century Britain and a private income usually essential. ${ }^{16}$ It was becoming less usual, however, to embark on archaeological excavation without some form of instruction. The methods-or rather lack of method-of amateurs increasingly incurred the wrath of the emergent profession. Attachment to an established archaeologist had been a course adopted by serious amateurs throughout the nineteenth century. ${ }^{17}$ Wellcome preferred to employ other workers to write up his archaeological findings. This did not protect his methods of excavation at Jebel Moya, where he personally supervised, from criticism. ${ }^{18}$ The later and more highly respected

\footnotetext{
${ }^{14}$ See, for example, Evidence, op. cit., note 1, above, p. 104.- "For years I spent much time in the British Museum Library and in studying the Museum collections."

${ }^{15}$ Christy's major achievement was the discovery of Palaeolithic art, with Edouard Lartet (1801-71). Glyn Daniel, A hundred and fifty years of archaeology, 2nd ed., London, Duckworth, 1975, pp. 95-96.

${ }^{16}$ On the professionalization of archaeology, see ibid., 164-166, 309-311. This work incorporates a useful bibliography of the history of archaeology and related studies. Tylor regarded himself as a professional anthropologist and was appointed to the newly created Readership in Anthropology at Oxford in 1884. In 1896, this became a personal chair. Cambridge did not create a comparable post until 1909 when A. C. Haddon was made Reader in Ethnology. See J. W. Burrow, Evolution and society, Cambridge University Press, 1966, pp. 234-241.

${ }^{17}$ Christy's initial attachment to Lartet had been on this basis. (See note 15 above.) Christy acted as mentor to the young E. B. Tylor on a collecting trip to Mexico. See Burrow, op. cit., note 16 above, pp. 242-243.

18 The Jebel Moya findings were eventually published. Frank Addison, Jebel Moya. The Wellcome Excavations in the Sudan vols. I and II, and, with O. G. S. Crawford, vol. III, Abu Geili. Frank Addison, Sagadi and Dar el Mek, Oxford University Press for the Wellcome Trustees, 1949-1951. Some idea of the methods used can be had from O. G. S. Crawford, Said and done, the autobiography of an archaeologist, London, Weidenfeld \& Nicolson, 1955, pp. 102. "The work was rendered unnecessarily arduous by Wellcome's instructions .... Every fragment ... had to be kept ... we were obliged to make a special
} 


\section{Sir Henry Wellcome's museum for the science of history}

expedition to the Near East in 1932 was mounted jointly with the biblical archaeologist, Charles Marston, with Wellcome essentially in the role of financial backer. He never visited the Lachish site and excavations were still in progress when he died.

Wellcome's only foray into scholarly publication in his adopted subjects seems to have been a short paper given to the International Congress of Medicine in 1913 (the year his historical medical exhibition opened) on an Egyptian bas-relief supposedly illustrating obstetrical instruments. ${ }^{19}$ The paper is brief and insubstantial by contemporary standards and more recent writers do not consider that the instruments are surgical. ${ }^{20}$ Wellcome himself exhibited some qualms, since he had the paper sent to the Egyptologist, W.M. Flinders Petrie (1853-1942), for comments. ${ }^{21}$ Although he joined many learned societies-the Royal Geographical, the Royal African, the Society of Antiquaries, the Royal Anthropological Institute-and achieved high office in some, there is no record that Wellcome presented a paper to any of them. He was undoubtedly closely associated with the London scientific community later in life, but earned his place in it through business success and philanthropy, rather than scholarly contribution. His election to the Royal Society was under Statute 12, which provided for the recommendation by the Council (i.e. not individual sponsors) for election of "persons, who ... either have rendered conspicuous service to the cause of science or are such that their election would be of signal benefit to the Society".22

Searching for intellectual influences which might have shaped Wellcome's conception of a historical medical museum, one must look before 1900, to anthropology, not medicine. By 1903, his ideas on the content of the museum had taken shape. They were laid out in a short leaflet appealing for historical items that

compound and pile in it classified and labelled heaps of this useless rubble." More seriously, Crawford alleges that Wellcome gave no instructions for levels to be taken when excavations stopped in 1914. "it was then too often forgotten that survey alone makes adequate record possible and that without it excavation is mere looting and destruction." Crawford spent three days levelling the site himself, p. 105. For more adulatory accounts of Wellcome's activities in the Sudan, see R. Kirk, 'Sir Henry Wellcome and the Sudan', Sudan Notes and Records, 1956, 37: 79-87; and Percy F. Martin, The Sudan in evolution, London, Constable, 1921. Two brief papers on the Jebel Moya findings were read at the Seventeenth International Congress of Medicine, London, 1913: M. B. Ray and L. M. Dudley Buxton, 'Some pathological and other conditions observed among the human remains from a prehistoric Ethiopian cemetery in the southern Sudan, Africa', XVIIth International Congress of Medicine, London, 1913, Section XXIII History of Medicine, London, Oxford University Press, 1914, pp. 231-236; and Douglas E. Derry 'Some physical characters of a prehistoric Sudanese race'. See also R. Mukherjee, C. R. Rao, and J. C. Trevor, The ancient inhabitants of Jebel Moya, Sudan, Cambridge University Press, 1955.

${ }^{19}$ Henry S. Wellcome, 'Graeco-Roman surgical instruments represented in Egyptian sculpture', XVIIth International Congress of Medicine, op. cit., note 18 above, pp. 207-209. In addition, Wellcome read a 2000-word account of preliminary work at Jebel Moya to the Archaeological Section of the British Association for the Advancement of Science, Dundee, 10 September 1912 (reprinted in Addison, vol 1, op. cit., note 18 above). Apart from an indication, in the most general terms, of the sort of objects found, the account is purely narrative, and concerns the practicalities of dealing with the natives, who, "notorious for their turbulence, expended their energies in hideous, all-night drunken orgies", p. 264. For a complete bibliography of Wellcome, mainly comprising early contributions to pharmaceutical journals, see the entry by R. C. E. Milligan in D. J. Jeremy (editor) Dictionary of business biography, vol. 15, London, Butterworth, 1986.

${ }^{20}$ See, for example, P. Ghalioungui, Magic and medical science in ancient Egypt, London, Hodder \& Stoughton, 1963, pp. 101-104 on this bas-relief.

21 Letter, probably C. J. S. Thompson to Flinders Petrie, 29 July 1913, WI:FC:IOB.

22 Statute 12, Statutes of the Royal Society p. 181; and 'Sir Henry Wellcome, FRS', Nature, 1932, $129: 822$. 


\section{Ghislaine M. Skinner}

year and they did not change, in essence, thereafter. ${ }^{23}$ Wellcome pursued his organization of the museum apparently without reference to others in the museum world. Despite encouragement from Sir Arthur Keith (1866-1955), the Wellcome Historical Medical Museum never joined the Museums Association although the Royal College of Surgeons' and Pharmaceutical Society's museums did so. ${ }^{24}$ Keith, who was closely associated with the Museum on a formal basis (he gave the address at the 1926 re-opening) and who, given his professional capacity as curator of the Royal College of Surgeons' Museum and the country's foremost human palaeontologist, might have been a natural confidant for Wellcome, makes it clear in his autobiography that he viewed him, not as a colleague, but as a potential benefactor of the impoverished Anthropological Institute. ${ }^{25}$

If Wellcome's financial resources allowed him to pursue his hobbies in a grand manner, they also supported his other major activity-philanthropy. Of his philanthropic activities, the great majority were connected with scientific ventures. $\mathrm{He}$ secured the closest connexions with scientific research that it was possible for a non-practitioner to have, through his financial and organizational capacity. ${ }^{26}$ It is conceivable that he considered himself to be a scientist, depending on the interpretation put on his remark that William Mayo, father of the surgical brothers, whom he had met in Rochester, "had insisted that I fit myself for a career in the field of science". ${ }^{27} \mathrm{He}$ took an optimistic view of the improving nature of science and was less concerned with directly ameliorating the condition of mankind through the provision of education, improved living conditions, or rational amusement. It was through science that most benefit would accrue and it was with scientific ventures that he chose to associate his name, usually compulsorily, as a condition of his philanthropy. In view of this, it is perhaps surprising at first sight that he chose to devote considerable resources to the foundation of, as well as research laboratories, a historical museum. After all, Sir Henry Cole (1808-82), had, in 1857, expressed the hope that museums would furnish "a powerful alternative to the gin palace", as somewhere that the working man might take his family for the evening. ${ }^{28}$ Rational amusement for the working man, however, was certainly not what Wellcome, forty years later, had in mind.

${ }^{23}$ Historical exhibition of rare and curious objects relating to medicine, chemistry, pharmacy and the allied sciences, WHMM, [n.d.].

${ }^{24}$ At Keith's specific request (see Report, Malcolm to Wellcome, WF:E2:DW, 'WHMM,1926'), his address at the reopening of the museum was reprinted in the Museums Journal (1926-1927, 26: 229-235). An account of the Museum by the conservator, C. J. S. Thompson, had appeared in 1916. It included photographs and drew heavily on the text of guide and handbook. C. J. S. Thompson, 'The Wellcome historical medical museum, London', Museums J., 1915-1916, 15: 349-356.

${ }^{25}$ Sir Arthur Keith, An autobiography, London, C. A. Watts, 1950, p. 356. According to Charles Singer, E. H. Starling also regarded Wellcome as a potential source of funds, in this case to endow a Chair of the History of Medicine at University College London. See letter, Singer to Ralph Colp, 22 August 1951, CMAC:P.P.P/CJS (Contemporary Medical Archives Centre, Wellcome Institute for the History of Medicine). By courtesy of the Wellcome Trustees.

${ }^{26}$ Philanthropy and "science" were sometimes rather unhappily combined. At Jebel Moya, Crawford was once obliged to find work for "no fewer than seven hundred men". Crawford, op. cit., note 22 above, p. 102.

${ }^{27}$ Henry S. Wellcome, 'Celebration of Lister centenary', Surgery, Gynec. Obstet. 1927, 856-858.

${ }^{28}$ Cole was specifically referring to evening opening of the South Kensington Museum. Henry Cole, 'Introductory address on the functions of the science and art department', 16 November 1857, in Cole, Fifty years of public work, London, 1884, vol. 2, p. 293. 
Closer inspection of the changes taking place in museums in the nineteenth century reveals just why the museum venture may have attracted him. Founded largely in the eighteenth century, the national and provincial museums of Britain were, in the early nineteenth century, in considerable disarray. The Romantics' concern with classical Greece and Rome had swelled their collections but not their assets. Miller chronicles the difficulties at the British Museum, and the early issues of the Museums Journal (founded 1901) contain numerous tales of the state of provincial museums in mid-century. ${ }^{29}$ The period was similarly a difficult one for European museums, but it was also one which saw the beginnings of profound change. This changing status of museums can be clearly associated with archaeological, and later anthropological, practice, and it is necessary to deviate at this point from Wellcome's venture in order to examine some more general issues within the history of these disciplines, particularly anthropology.

Of the two works which Daniel considers crucial to the development of archaeology in the first half of the nineteenth century, one was a museum guide. ${ }^{30}$ In this, the guide to the Copenhagen Museum of 1835, C. J. Thomsen (1788-1865) introduced his Stone, Bronze and Iron Age classification, based largely on work on the Museum's collections. ${ }^{31}$ The importance laid on the systematic arrangement of artefacts by archaeologists and anthropologists was to lead, by the end of the century, to museums being viewed in large part as centres for research rather than relaxation, for edification of the specialist, and in particular the scientist, rather than education of the masses. In 1854, John Edward Gray (1800-75), in his address to the British Association for the Advancement of Science as President of Section D, had described the two purposes for which museums were established. "First, the diffusion of instruction and rational amusement among the mass of the people, and, secondly, to afford the scientific student every possible means of examining and studying the specimens of which the museum consists." 32 By 1893, in Sir William Flower's presidential address to the five-year-old Museums Association, the "first duty" of museums had become "without question to preserve the materials upon which the history of mankind and the knowledge of science is based". ${ }^{33}$ By 1904, in Henry Balfour's presidential address to the Anthropological Institute, museums were to be the "laboratories of anthropologists". ${ }^{34}$ What is striking here is not only the changing perception of the role of museums - they were to be centres of scientific research rather than public edification-but also the extent to which they were to deal with the "history of mankind". Balfour (1863-1939), curator of Pitt-Rivers' collections, housed at Oxford University from 1883 , might perhaps be expected to stress this role, but Flower

${ }^{29}$ E. Miller, That noble cabinet, London, Deutsch, 1973. The Elgin marbles, acquired in 1816, were kept in a "temporary shed" until 1831, p. 107.

${ }^{30}$ Daniel, op. cit., note 15 above, p. 45. The other was J. J. A. Worsaae, The primeval antiquities of Denmark, translated by W. J. Thoms, London, 1849.

${ }^{31}$ Christian Jurgensen Thomsen, Ledetraad til Nordisk Oldkyndighed, Copenhagen, 1836. An English translation by Lord Ellesmere appeared in 1848 entitled $A$ guide to northern antiquities.

32 Quoted in Sir William Flower, presidential address to the Museums Association, reprinted in Nature, 1893, 48: 234-235.

${ }^{33}$ Ibid., p. 234. 19.

${ }^{34}$ Henry Balfour, 'The relationship of museums to the study of anthropology', J. Anthrop. Inst., 1904, 34: 


\section{Ghislaine M. Skinner}

(1831-99), first Director of the Natural History Museum, was addressing curators from all types of museum, and still felt able to prescribe "history" and "mankind" as the prime concerns for all. By the end of the nineteenth century, a "museum" implied an exposition of developmental history, rather than a cabinet of curiosities. ${ }^{35}$

The scientific study of the history of mankind was, of course, precisely the goal which, after the publication of Darwin's theory of evolution and Spencer's advocacy of a "science of society", the evolutionist founding fathers of anthropology set themselves. "Anthropology began as the science of history" and grew from nothing to maturity in the decades $1860-90 .^{36}$ Workers such as E. B. Tylor (1832-1917) and L. H. Morgan sought nothing less than a universal "scientific" history of man in all his aspects (or, as this totality came to be known, "culture"). This they perceived as an essentially regular progression, through various stages of "civilization" as man transcended, by means of his rationality and inventiveness, enslavement to his basic animal needs. The process was universal, and law-like, and for the evolutionist school, unchallenged until the 1890 s, anthropological enquiry consisted of the reconstruction of this sequential progress. Preoccupied as they were with origins, they acknowledged their debt to archaeologists, both for the concept of prehistory and for the methods used to reconstruct it. As Lowie says, "prehistory proved evolution . . . no wonder that ethnographers leaned heavily on the staff of archaeology". ${ }^{37}$ Archaeological evidence alone, however, was awkwardly silent on aspects of culture to which the evolutionists attached great importance, such as belief systems. Their conception of the essential psychic unity of mankind, and in consequence the generally regular nature of man's progression through various stages of civilization-in Morgan's scheme, from savagery through barbarism to civilization-made possible its reconstruction "largely by means of a special and much debated procedure known as the comparative method", using which "all theorists of the latter half of the 19th century proposed to fill the gaps in the available knowledge of universal history". ${ }^{38}$ The origins of this method, whereby contemporary "primitives" were taken to represent earlier, prehistoric stages of development, have been variously attributed. ${ }^{39}$ Enlightenment theories of progress,

\footnotetext{
${ }^{35}$ On historical representation "in the broadest sense", see Stephen Bann, The clothing of Clio, Cambridge University Press, 1984, especially ch. 5 'Poetics of the Museum: Lenoir and Du Sommerard', pp. 77-92.

${ }^{36}$ Marvin Harris, The rise of anthropological theory, New York, Thomas Y. Cromwell, 1986, p. 1. Earlier general histories of anthropology are: A. C. Haddon, History of anthropology, London, Watts, 1910; T. K. Penniman, A hundred years of anthropology, London, Duckworth, 1935; and R. H. Lowie, The history of ethnological theory, New York, Holt, Rinehart \& Winston, 1937. Harris, writing from a Marxist viewpoint, pays particular attention to the evolutionist school. A more recent reappraisal is to be found in Fred. W. Voget, A history of ethnology, New York, Holt, Rinehart \& Winston, 1975. Burrow, op. cit., note 16 above, is still unsurpassed on the influence of evolutionary thought on Victorian social theory. It includes a useful bibliography as does the introductory text, D. R. Oldroyd, Darwinian impacts, Milton Keynes, Open University Press, 1980. More extensive bibliographical notes are contained in George W. Stocking jun., 'The history of anthropology: where, whence, whither?', J. Hist. Behav. Sci., 1966, 2: 281-290. Most comprehensive is Robert V. Kemper and John F. S. Phinney, The history of anthropology. A research bibliography, New York and London, Garland Publishing, 1977.

37 Lowie, op. cit., note 36 above, p. 32.

38 Harris, op. cit., note 36 above, p. 150.

39 On the origins of the comparative method, see Burrow, op. cit., note 16 above, pp. 11-13; Harris, op. cit., note 36 above, pp. 151-153; Lowie, op. cit., note 36 above, pp. 19-29.
} 


\section{Sir Henry Wellcome's museum for the science of history}

biology, eighteenth-century linguistics, and nineteenth-century geology have all been cited as sources, the last clearly acknowledged by Lubbock when he remarked that "the van Diemaner and South American are to the antiquary what the opossum and the sloth are to the geologist". ${ }^{40}$ Wherever the origins of the method lay, its use became a sine qua non of the evolutionary anthropologists. A corollary of the comparative method was the search for "survivals". Defined by Tylor in 1871 in Primitive culture as "processes, customs, opinions and so forth, which have been carried by force of habit into a new society... and ... thus remain as proofs and examples of an older condition of culture out of which a newer has evolved", survivals provided the rationale for the studies of the folklorists who, together with physical anthropologists, were to dominate British anthropology in the late nineteenth century. ${ }^{41}$ The shared goals and methods of folklorists and evolutionist anthropologists were revealed in such titles as "Folklore as an historical science" by G. L. Gomme (1853-1916) ${ }^{42}$

Survivals were invaluable to those who sought a "scientific" reconstruction of the past, peeling back "layer after layer of the psycho-historic strata in man's progress until the very bedrock of man's intellectual beginnings had been reached". ${ }^{43}$ In a way that reveals their ever-present debt to the disciplines of archaeology and geology, anthropologists drew frequent analogies between survivals and material remains. Morgan, applying the doctrine of survivals to problems of descent, referred to "relics", "traces", "outcrops", and "remains". ${ }^{44}$ Another frequent analogy derived from biology. Survivals were often equated with rudimentary organs. ${ }^{45}$ Indeed, the interchangeable nature of "thoughts" and "things" is a striking feature of the evolutionist school. "Defining the essential process of reality in terms of thought", Tylor, Morgan, and other "psychogenic evolutionists" as Voget consequently calls them, looked to "institutions, inventions and discoveries" to reveal the mental history of the human race. ${ }^{46}$ They would doubtless have agreed with Thoreau, for whom a flint arrowhead had been "but a fossil thought". ${ }^{47}$ This concept became very widely accepted - "the work of primitive hands is but the tangible expression of primitive thought", read the handbook to the British Museum's ethnographic collections, first published in $1910 .^{48}$

From amongst the evolutionist school, the name most closely associated with reconstructing the history of mankind through his artefacts is, of course, Pitt-Rivers. ${ }^{49}$

\footnotetext{
40 John Lubbock, Primitive times, as illustrated by ancient remains and the manners and customs of modern savages, London, Williams \& Norgate, 1865, p. 416, quoted by Harris, op. cit., note 36 above, p. 152.

4 E. B. Tylor, Primitive culture, London, John Murray, 1871, p. 16. A whole volume has been devoted to the history of the concept of survivals: M. T. Hodgen, The doctrine of survivals, London, Allenson, 1936.

${ }^{42}$ G. L. Gomme, Folklore as an historical science, London, Methuen, 1908.

${ }^{43}$ Fred, W. Voget, 'Man and culture: an essay in changing anthropological interpretation', in Regna Darnell (editor), Readings in the history of anthropology, New York, Harper \& Row, 1974, pp. 343-383.

44 Harris, op. cit., note 36 above, p. 165.

45 Ibid.

46 Voget, op. cit., note 43 above, p. 347.

${ }^{47}$ Henry David Thoreau, Journals (edited by Bradford Torrey and Francis H. Allen), New York, Dover, 1962, 28 March 1859 quoted in Schlereth, op. cit., note 7 above, p. xvi.

${ }^{48}$ British Museum Handbook to the ethnographical collections, Oxford University Press, 1910, p. 43.

${ }^{49}$ For a short biography of Pitt-Rivers, see M. W. Thompson, General Pitt-Rivers. Evolution and archaeology in the nineteenth century, Bradford-on-Avon, Moonraker Press, 1977. See also Harold St George Gray, A memoir of Lieut-General Pitt-Rivers, first published in the index to Excavations on Cranbourne Chase, privately printed, 1905, recently re-issued in facsimile by the Pitt Rivers Museum,
} 


\section{Ghislaine M. Skinner}

This professional soldier turned archaeologist and anthropologist devoted much of his inherited wealth and estates to his adopted disciplines and has been seen as instrumental in creating modern archaeological method. ${ }^{50}$ His anthropological theory was less innovative, but his major contribution, drawing heavily on biological analogy, was to make full use of the concept of the interchangeable nature of thought processes and artefacts. "Human ideas as represented by the various products of human industry are capable of classification into genera, species and varieties, in the same manner as the products of the vegetable and animal kingdoms, and in their development from the homogenous to the heterogenous they obey the same laws. If, therefore, we can obtain a sufficient number of objects to represent the succession of ideas, it will be found that they are capable of being arranged in Museums upon a similar plan." 51 This Darwinian conception of the evolution of man's material culture by minute changes (with "utility" substituted for natural selection) was ideally suited to reconstructing and representing the progressive "psychogenic" history of mankind, if the comparative method was used. "The existing races, in their respective stages of progression, may be taken as the bona fide representatives of the races of antiquity ... whose implements, resembling, with but little difference, their own, are now found low down in the soil."52 Pitt-Rivers' efforts in constructing huge "typological" object sequences were cited with approval by Tylor and the evolutionist school. ${ }^{53}$ Even those "mentalists", such as James Frazer (1854-1941) and R. R. Marett (1866-1943), whose personal interests lay totally in the realm of the mind, acknowledged the importance of the study of material culture in the grand reconstructive scheme. Museum collections were formed as integral parts of university departments of anthropology, often jointly administered with archaeologists. PittRivers' own collection was accepted by Oxford University in $1884 .^{54}$

A historical account of the development of culture also made possible the rearrangement of existing collections of antiquities-items collected originally because they were very old, and ethnographic objects, collected because they were very "foreign" or curious, into a coherent reconstruction of the past in museums not directly related to centres of archaeological or anthropological research. Museum curators, following the example of librarians, had formed a professional

Oxford, [n.d.]; and the introduction to Beatrice Blackwood, The classification of artefacts in the Pitt Rivers Museum, Oxford, Oxford University Press, 1970. As these titles indicate, there is no consensus on the use of the hyphen. Pitt Rivers did not use it, though his descendants have. The Museum does not, but Thompson considers it is now "normal" to do so. I have therefore used it in the text.

${ }^{50}$ Daniel, op. cit., note 15 above, pp. 169-174.

51 Augustus Pitt-Rivers, 'The principles of classification', in J. L. Myres (editor), Augustus Pitt-Rivers. The evolution of culture and other essays, Oxford, Clarendon Press, 1906, p. 18.

52 Ibid.

53 Tylor, op. cit., note 41 above, pp. 64-65.

${ }^{54}$ Blackwood, op. cit., note 49 above, p. 11 . On the early history of ethnographical collections at Cambridge and their intimate relationship with archaeological material, see the small but informative $V$. Ebin and D. A. Swallow, The proper study of mankind . . ., Cambridge University Museum of Anthropology and Archaeology, 1984, pp. 10, 11. For an account of the role of museums in the development of anthropology in Britain, see D. K. van Keuren, Human science in Victorian Britain: anthropology in institutional and disciplinary formation 1863-1908, (University of Pennsylvania PhD), University Microfilms, 1983, ch. 3; and of material culture studies in anthropology, George W. Stocking jun. (editor), Objects and others, Madison, University of Wisconsin Press, 1985. 


\section{Sir Henry Wellcome's museum for the science of history}

organization-the Museums Association-in $1888 .{ }^{55}$ They were soon urged, through its channels, to use the evolutionist account which promised to breathe new life into, or at least blow the dust off, their collections of curiosities. No longer, said Henry Balfour, would "the familiar 'cannibal club from the South Seas' languish against its neighbour, as likely as not a stuffed 'Egyptian ibis" " or "the label drop from 'the authentic Dagger which killed Captain Cook' henceforth to adorn the back of the unsuspecting 'Turtle from the West Indies' below". Nor would the museum become a "mere scrap-heap of 'curios', a burden and then an eyesore, handed over to a committee à discretion of moths, beetles, dust and damp". ${ }^{56}$ These words come from his presidential address to the Anthropological Institute in 1904. "One must pay a well-deserved tribute to that excellent organization, the Museums Association", he continued, "which ... has already done much towards promoting a healthy activity in the Museum world and towards shaming out of existence any retrogressive tendencies". ${ }^{57}$ The links between the museum world and the archaeologists and anthropologists who had provided it with a new mandate were never stronger than at the turn of the nineteenth century. Balfour himself was Tylor's successor at the Pitt-Rivers Museum and President of the Museums Association in $1909 .{ }^{58}$ Proceedings of the Association, and early issues of its journal, published from 1901, show a preoccupation with both archaeological and ethnographical material and with the methods of the evolutionist anthropologists. Repeated pleas were made for the exhibition of prehistoric material in close conjunction with ethnographic and for the use of Pitt-Rivers' "typological" arrangements in place of the geographical grouping of ethnographic objects commonly employed.$^{59}$ It was often agreed that Pitt-Rivers' arrangement was more "scientific" and, when not adhered to, this was said to be because of insufficient material or inadequate accommodation. ${ }^{60}$

Museums had become places where the science of history was practised and it is clear that Wellcome regarded the museum venture as furthering scientific knowledge just as much as his physiological and chemical research laboratories (founded in 1894 and 1896 respectively). The historical medical museum was always listed together with his laboratories and he intended it to be housed with them as part of the Wellcome Research Institution opened in 1931 (plate 6). ${ }^{61}$ Frequent mention was made of its "strictly scientific" nature, and this was not only in published material, where the museum was at pains to contradict any suggestion of it "advertising" for the drug

${ }^{55}$ Museums Association, 'Report of Proceedings, First Annual General Meeting, Liverpool, June 17-19, 1890 , together with a short account of the formation of the association'. The Yorkshire Philosophical Society was instrumental in the foundation of the new association.

56 Balfour, op. cit., note 34 above, p. 13.

57 Ibid.

58 Blackwood, op. cit., note 49 above, p. 11.

59 See, for example, H. I. Smith, 'The ethnological arrangement of archaeological material', Proc. Mus. Assoc., 1898: 143-149; H. S. Harrison, 'Notes on one kind of museum', Museums J., 1911-12, 11: 315-319 - the kind of museum referred to is a "museum of evolution".

${ }^{60}$ On the feasibility and benefits of adopting Pitt-Rivers' scheme, see Henry Balfour, 'Notes on the arrangement of the Pitt-Rivers Museum', Proc. Mus. Assoc., 1897, 51-54; F. W. Rudler, 'On the arrangement of ethnographical collections', ibid., 52-61, and the ensuing discussion of both papers, pp. 61-62.

${ }^{61}$ See The Wellcome Research Institution and the affiliated research laboratories and museums founded by Henry S. Wellcome, London, Wellcome Foundation, 1932.

62 This had been a recurring problem. See Johnston-Saint, op. cit., note 2 above. 


\section{Ghislaine M. Skinner}

company. ${ }^{62}$ In 1926, the curator was assuring Wellcome that "no effort is being spared to bring the Wellcome Historical Medical Museum into line with, or even ahead of, the scientific institutions in London". 63

In transforming their museums from what were essentially cabinets of curiosities into historical accounts of man in all his aspects, curators were satisfying a growing public curiosity. Throughout the decades when anthropologists were establishing their academic discipline, prehistory and man's origins had captured the public imagination. These were, of course, Wellcome's formative years. In Britain, Daniel considers The antiquity of man, Nineveh and its remains, Lubbock's Prehistoric times, and the Descent of man as crucial to this popularization. ${ }^{64}$ The Society for the Protection of Ancient Buildings was founded in 1877, the Folklore Society in $1878 .^{65}$ The fascination exerted by "dumb relics" of prehistory is stressed by both Daniel and Burrow. ${ }^{66}$ Certainly exhibitions of "relics" such as the giant fossils exhibited in America and Britain throughout the nineteenth century pulled large crowds. ${ }^{67}$ The Great Exhibition of 1851 showed a collection of prehistoric tools, and Henry Christy attributed his subsequent interest in archaeology to seeing these. ${ }^{68}$ The work of Heinrich Schliemann (1822-90) at Troy and Sir Arthur Evans (1851-1941) at Knossos was followed with avid concern by the British public. ${ }^{69}$ From 1917 to 1919 , lectures by Arthur Keith on the origins of the British races were to form the basis of a popular column in the Evening Standard. ${ }^{70}$ It comes as no surprise to find that Wellcome dated his own interest in what he usually referred to as "the great past" to an occasion when, at the age of four, he was shown a "relic"-in this case a sharpened flint-by his father. ${ }^{71}$ Brought up in the American mid-west, he was exposed, of course, to more than dumb relics of "primitive" cultures. It has been suggested that Wellcome's contact with the American Indian stimulated his interest in the history of man. ${ }^{72}$ This seems to have been the case for several of his more eminent predecessors, notably $\mathrm{L}$. $\mathrm{H}$. Morgan-one of "a long line of Indianophiles stretching back to Bartolomé de las Casas". ${ }^{73}$ Wellcome maintained, throughout his life, a charitable involvement with Father William Duncan's Christian settlements for Tsimshean Indians, known as Metlakahtla and New Metlakahtla, in Alaska. A "humanitarian mission" connected with this cause prevented him from attending the 1926 reopening of the Historical Medical Museum. Wellcome eulogized Duncan's work in The story of Metlakahtla,

${ }^{63}$ Letter from Malcolm to Wellcome, 6 July 1926, p. 5. W.F:E2:DW. 'WHMM, 1926'.

64 Daniel, op. cit., note 15 above, pp. 32-33.

${ }^{65}$ See A. D. Saunders, 'A century of ancient monuments legislation 1882-1982', Antiquaries J., 1983, 63: 11-33; and Hodgen, op. cit., note 41 above, p. 68.

66 Burrow, op. cit., note 16 above, p. 117; Daniel, op. cit., note 15 above, p. 116.

${ }^{67}$ See Altick, op. cit., note 4 above, pp. 288-289, on these attractions.

68 Burrow, op. cit., note 16 above, p. 242; and Thompson, op. cit., note 49 above, p. 21. Curiously, Daniel states that "The Great Exhibition of 1851 contained no prehistory", op. cit., note 15 above p. 115 .

69 Ibid., pp. 138, 140, 191-192.

${ }^{70}$ Keith, op. cit., note 25 above, p. 401.

71 See Evidence, op. cit., note 1 above, p. 105.

72 See, Turner, op. cit., note 9 above, pp. 23-24, for example.

${ }^{73}$ Harris, op. cit., note 36 above, p. 139. Morgan published League of the Iroquois in 1851, "largely for humanitarian reasons". Tylor, speaking in Montreal, was of the opinion that "Here in America one of the great problems of race and civilization comes into closer view than in Europe ... we can still study among the settled Iroquois the type of a race lately in the Stone Age". Edward B. Tylor, "American aspects of anthropology', in Darnell (editor) op. cit., note 43 above, p. 218. 


\section{Sir Henry Wellcome's museum for the science of history}

which he published privately in 1887 , devoting the proceeds to the Indian settlement. ${ }^{74}$ In chapter $\mathrm{V}$ of the book, entitled 'The savage', establishing the primitive character of the Indians, he quotes Tylor at length and, briefly, Lubbock and others. ${ }^{75}$ Wellcome indulged his interest in "the great past" by collecting antiquities and curios throughout his adult life. ${ }^{76}$ In 1903, he began in earnest to collect material for a "historical medical exhibition". In circulars to representatives of Burroughs Wellcome, to medical men, and to missionaries he announced his intention of holding an exhibition in connexion with the history of medicine, with the object of "stimulating the study of the great past". One circular indicated that the exhibition would be to mark the twenty-fifth year of trading by Burroughs Wellcome (1904), another that its prime purpose was to retrieve potentially useful ancient medicaments, a third that it would concentrate, rather curiously, on "anything which has been used for the purposes of fraud ... such as false weights and measures . ..."77 However, these early roles for the exhibition were soon lost sight of, if indeed they had ever seriously existed. The venture had begun to assume a rather different and grander character by the time an exhibition did open in 1913. Some indication of what this was to be is to be had from the Museum records of the intervening decade of most intensive acquisition. It is clear that the prime function of the curator, C. J. S. Thompson (1862-1943), whom Wellcome employed in various capacities from 1896, was to collect. Thompson's reports detail an unceasing round of visits to dealers, auction houses, private vendors, museums, and libraries in Britain and abroad. By 1909 , many thousands of items had been acquired. ${ }^{78}$ Wellcome kept close control over the collecting, marking up sale catalogues and deciding purchasing prices. He was undoubtedly aware that job lots were often purchased, sometimes containing large numbers of apparently identical objects, paintings, and objets d'art of doubtful or absent provenance, ethnographic material of any kind, and more sophisticated items lacking any apparent connexion with the history of medicine. ${ }^{79}$

${ }^{74}$ Henry S. Wellcome The story of Metlakahtla, London, Saxon, 1887. On the unusual Christian Indian societies established by Duncan see Jean Usher, William Duncan of Metlakahtla, Ottawa, National Museums of Canada, 1974; and Peter Murray, The devil and Mr Duncan. A history of the two Metlakahtlas, Victoria, B.C., Sono Nis Press, 1985.

${ }_{75}$ Wellcome, op. cit., note 74 above, pp. 151-153, 149.

${ }^{76}$ Evidence, op. cit., note 1 above, p. 106.

${ }^{77}$ Op. cit., note 23 above. See also Historical exhibition of rare and curious objects relating to medicine, chemistry, pharmacy and the allied sciences to be held in London shortly, [n.d. probably 1903-4], and a longer pamphlet with the same title, [n.d. but probably between 1906 and 1910]; and Historical Medical Exhibition, London, 1913 advance notice, [n.d. probably $c$. 1911]. All WI:FC.9a 'WHMM Notices and circulars 1913 exhibition'.

${ }_{78}$ See, for example, Report, Thompson to Wellcome, 5 January 1909, WI:FC:9a, in which Thompson is asking for assistance with surgical instruments, "of which there are already several thousand". Thompson began to collect specifically for the Museum in 1903, whilst nominally "Librarian". His official title was changed to "Curator" in 1913.

${ }_{79}$ Collections of sale catalogues marked up by Wellcome exist in the Wellcome Institute Archives. All eleven of the major auction houses then operating in London were regularly patronized. Assumptions that Wellcome inadvertently acquired large amounts of unwanted material through the sharp practices of auctioneers, or the unselective nature of the collecting, are not necessarily correct. See, for example, the catalogue for a sale at Stevens in 1928. The Museum was bidding, on Wellcome's instructions, for Lot 303 (eight pairs of Cornets forceps) and, eight lots later, for Lot 311 (eighteen pairs of Cornets forceps). For an instance of the Museum refusing material, in this case natural history specimens, see Report, Malcolm to Wellcome, 5 October 1926, WF:E2:DW 'mixed dates, 1912-58'. There are indications throughout Museum reports that Wellcome knew what was being acquired, that he closely directed acquisition, and that the enormous (but not limitless) diversity of items was certainly intentional. 


\section{Ghislaine M. Skinner}

In 1913, the collection was appointed the official museum to the Seventeenth International Congress of Medicine, held in London. The Royal College of Surgeons' Museum had been approached initially but was unable to mount an exhibition since their resources were committed elsewhere. ${ }^{80}$ Wellcome's 1913 exhibition re-opened in its Wigmore Street premises in 1914, and from then onwards was known as the Wellcome Historical Medical Museum. A fairly detailed account of the aims of the museum can be had from the guides and handbooks published intermittently from $1913 .^{81}$

In view of the pervasive influence of anthropology on museums, it is perhaps not so surprising to discover that this historical medical museum was to be nothing other than a "scientific" reconstruction of the development of a cultural activity, by means of the search for origins, that was the goal of evolutionist anthropologists. It is striking just how closely the Museum mirrored the preconceptions and the preoccupations of the nineteenth-century evolutionists. "One of the central aims of this Museum is to connect the links in the chain of human experience which stretch back from the present time into the prehistoric period of the early ages." (Later, "the most remote ages of the great past".) "... Efforts will be made to trace the genesis of many branches of the healing art ..." 82 Information was to be sought in "folklore", "items of curious medical lore", "early traditions", and "quaint customs"-in other words, survivals. ${ }^{83}$ Origins were to be sought most directly, however, in ethnographic material, which, by 1926, accounted for almost three-quarters of the collection. The Hall of Primitive Medicine (plate 1) had, since 1914, occupied almost a quarter of the main floor of the Museum. ${ }^{84}$ The exhibition handbook of 1913 had had very little introductory text. The handbook to the Museum, first published in 1914, provided in this and the 1920 edition, 1,000-word introductions only to the two parts of the Hall of Primitive Medicine. In these, clear statements of the comparative method are to be found. In 1920: "in many of the practices and customs common among primitive races today in the treatment of disease we find a reflection of what medicine must have been in very early times in Europe". ${ }^{85}$ And, in 1927: "the practice of the healing art may be traced in part from prehistoric days, and a reconstruction can be attempted by a study of primitive and folk medicine .... Light can also be thrown on many obscure practices by a study of primitive and folk medicine." 86 The second section of the Hall of

\footnotetext{
${ }^{80}$ See Museums J., 1912-1913, 12: 255.

${ }^{81}$ For Wellcome's decision to re-name the exhibition, see memo from Thompson to Linstead, 17 July 1912. WI:FC.9b 'B. W. \& Co, London, 1903-1912'. The Museum guides and handbooks comprise: Handbook of the Historical Medical Museum organised by Henry S. Wellcome. (XVIIth International Congress of Medicine), London, Wellcome Historical Medical Museum, 1913. Handbook to the Wellcome Historical Medical Museum, London, [WHMM], 1914 (also later editions, 1920, 1927.) Guide to the Wellcome Historical Medical Museum. London, [WHMM], 1927.

${ }^{82}$ Guide (1927) p. 14; Handbook (1927), pp. 6-7.

83 Op. cit., (1906-10), note 77 above, p. 1.

84 See the "general plan" of the Wellcome Historical Medical Museum included in all editions of the Guide and Handbook from 1916.

${ }^{85}$ Handbook (1920), p. 6.

${ }^{86}$ Guide (1927), p. 6.
} 


\section{Sir Henry Wellcome's museum for the science of history}

Primitive Medicine dealt with "amulets, charms and talismans employed in folk medicine in various parts of the world", which were described as "closely allied to the objects related to the healing art among primitive peoples". 87 "The use of amulets has been common among all races from the earliest times, and has survived to the present day. This belief in the occult effect of certain objects exhibits the lower stages of the human mind in seeking for principles of natural action, and is found not only among the most barbaric tribes, but also among the highest civilised peoples of today. ${ }^{88}{ }^{8}$ Here were displayed not only charms and amulets from ancient and primitive societies, but "the 'mascots' carried by credulous persons at the present day". ${ }^{89}$

In 1926, C. J. S. Thompson was replaced by L. W. G. Malcolm (1888-1946) as conservator. Overtly, Wellcome maintained that Thompson had infringed certain restrictions on publication. It is possible, however, that Wellcome's real discontent lay in the fact that, although many thousands of objects had been acquired, the Museum was not developing along the lines he was to describe so clearly to the Royal Commission on Museums and Galleries two years later. Always insistent that the Museum was "scientific" and was to become a centre for "research", he may have felt that Thompson, who, by his own admission, cultivated a journalistic style, and who appears to have continued to work as a freelance writer, was not the man for this task. $^{90}$ Thompson had, since 1899 , written numerous articles and books on various aspects of medical history, with such titles as Poison mysteries in history, romance and crime, and it is difficult to imagine that Wellcome was unaware of this. ${ }^{91}$ Malcolm, the new conservator, had more attractive credentials-a master's degree in anthropology from Cambridge where he had been a pupil of A.C. Haddon (1855-1940) and W. H. R. Rivers (1864-1922), and a previous position as curator in change of Archaeology and Ethnography at the Bristol Museum. ${ }^{92}$ "In future", instructed Wellcome, "the Museum is to be run on strictly scientific lines." 93 "We have often discussed the policy of this Museum and I have always been on 'all fours' with your ideas regarding the arrangement of the objects showing the evolutionary development of each series", wrote Malcolm. ${ }^{94} \mathrm{He}$ then drew up a staff list. "The Wellcome Historical Medical Museum will have definite sections, each of which will be dealt with by a responsible

${ }^{87}$ Handbook (1920), p. 9.

${ }^{88}$ Ibid.

${ }^{89}$ Ibid.

${ }^{90}$ For biographical details of Thompson, orginally trained as a pharmacist, see his obituary notices in the Br. med. J., 1943, ii: 153; and Lancet, 1943, ii: 108-109; and Leslie G. Matthews, 'C. J. S. Thompson memorabilia', Pharm. J., 1979, 223: 658-659. His aspirations were towards journalism. See Report, Thompson to Wellcome 4 February 1907, WI:FC:9A. In 1914, for example, he was offering articles on Nietzsche and Bernoulli to the Morning Post (see WI:FC:10b). In 1927, he succeeded Alban Doran as honorary curator of the Royal College of Surgeons historical collections, through the offices of Sir Arthur Keith. The Fellows appreciated his talents, as evidenced by the small collection of Thompson letters deposited with the Royal Pharmaceutical Society.

${ }^{91}$ C. J. S. Thompson, Poison mysteries in history, romance and crime, London, Scientific Press, 1923.

${ }^{92}$ For biographical details of Malcolm, see his obituary notice, Museums J., 1946, 46: 174, and his curriculum vitae in application papers to the London County Council for the posts of "organiser of museum activities", and Director of the Horniman Museum, S.O. 183, 27 May 1935, Enclosure 116 and S.O. 124, 5 July 1937, Enclosure 185. Education (General Purposes Sub-) Committee, Greater London Record Office. He was successful in both these applications.

${ }^{93}$ Letter, Wellcome to Malcolm, WF:E2:DW 'WHMM 1926'

${ }^{94}$ Letter, Malcolm to Wellcome, 6 July 1926, WF:E2:DW. 'WHMM 1926'. 


\section{Ghislaine M. Skinner}

assistant." The sections requiring full-time assistants were to be: Prehistoric archaeology, Classical archaeology, Antiquities, Folklore, Ethnology, and Racial Development with Physical Anthropology. ${ }^{95}$ Scientifically-trained staff were appointed in 1928 - four anthropologists, a Near Eastern, a classical and a prehistoric archaeologist. $^{96}$

It is clear from Malcolm's staff requirements that he considered the history of medicine as subsumed into the universal history which was anthropology. That this was also Wellcome's view had been apparent in the Museum's treatment since the earliest days. The printed material from the 1903 circular onwards - the exhibition guide of 1913 and the subsequent editions of the Museum guide and the handbook of 1927 do not indicate a major change of approach on Malcolm's appointment in 1925, although Wellcome was sufficiently dissatisfied with the layout of the Museum to close it for six months in order that Malcolm might make a "complete rearrangement". 97 This rearrangement, however, was largely in the detailed layout. The main organizational features remained very much as Wellcome had first planned them before 1913. In the Wigmore Street building, three major named areas-a Hall of Primitive Medicine (plate 1), a Hall of Statuary (plate 2), and a Picture Gallery (plate 3)-occupied most of the "first" floor-actually at street level. Smaller areas, identified only as vestibules, corridors, and the like in the guide books, and the ground (actually basement) floor were occupied by groupings of one type of object, such as drug jars, surgical instruments, or medicine chests (plate 4). Reconstructed pharmacies and other room settings were also placed in the basement. The major emphasis was firmly on primitive culture, and representational art. The large Hall of Primitive Medicine formed an obligatory introduction to the Museum. It was not possible to enter any other part, or the lower floor, without crossing it. Other than this there was no attempt at an overall chronological sequence in the Museum, or at grouping different kinds of object of the same period together. Within the groupings of similar types of object, however, sequence was of paramount importance. Surgical instruments, for example, displayed at various locations in the Museum, were arranged in sequences of single types - the trepan (plate 4a), the speculum, the dental forceps, and so on. "As far as possible the scheme is evolutionary and the series are so arranged that the history of each instrument may be studied separtely."98 "The evolution of the lancet" (plate 4b) showed the finger-nail, the shell, and sharpened flint as the earliest forms. A section on medicines dealt first with animal medicine, including materia medica used by the animal creation, followed by objects associated with the art of healing in Morgan's stages of society-savage, barbaric, and other primitive peoples, and early civilizations. A display of weaponry began with animal tusks and ended in the repeat firing musket. Similar hypothetical sequences dealt with, for example, the evolution of the surgical knife, the stethoscope, the toothbrush, the enema, and, later, "the evolution of the gas mask". 99 Wherever possible, the earliest examples in each

${ }^{95}$ Report by Malcolm 'Wellcome Historical Medical Museum', 1928. WI:FC.11b 'WHMM \& WHML'.

${ }^{96}$ Personal communication, H. J. M. Symons, Wellcome Institute Library.

97 'Wellcome Historical Medical Museum, Notice of closure. Temporarily closed for alteration and reorganization' states that the Museum will remain closed from 1 December 1925 to 31 May 1926. WI:FC.8c. 'WHMM. Printing Specimens, 1913-1946'.

98 Guide (1927), p. 14.

${ }^{99}$ Handbook (1927), p. 63. 


\section{Sir Henry Wellcome's museum for the science of history}

sequence were parts of the body and then natural objects. To complete the later parts of surgical instrument sequences, Malcolm removed hundreds of single items from eighteenth- and nineteenth-century boxed instrument sets. ${ }^{100}$

Wellcome was obliged to be abroad during most of 1926 and 1927 when Malcolm was reorganizing the Museum and mounting an exhibition on Lister. This necessitated most frequent and detailed reports from the new conservator to his absent, but vigilant, employer. One of the clearest statements of Wellcome's views is to be found in these exchanges. He provided notes on the subject he proposed Sir Arthur Keith should cover in his address at the reopening ceremony of 1926-'The Evolution of Man and Medicine'. Subject to Sir Arthur's views, Wellcome suggested he should:

Treat on purely scientific lines an estimation of the history from the beginning of the creation of the most primitive life with its accompaniment of disordered and diseased conditions affecting animate creatures, and the counter-acting healing arts and agents provided by nature and self-applied or otherwise. Trace from the awakening dawn through the principal stages of evolution the varying forms of primitive life up to the full development of mankind through all periods - contending against maladies and deadly pests, but ever aided by the evolution of remedial means and measures, protective and curative.

He instructed Malcom to:

Explain to Sir Arthur the plans on which we are working in the Museum to illustrate in our collection the whole story of life from the conversion of the inorganic into the organic cell, and so on through the ages. Also explain that $I$ have for many years been collecting for the purpose of demonstrating by means of objects that will illustrate the actuality of every notable step in the evolution and progress from the first germ of life up to the fully developed man of today. Furthermore, we aim to illustrate the continuous perils and ravages of disease encountered in the battle of life. Also the weapons to combat and the shields to protect. ${ }^{101}$

Rather more formal, but essentially similar, statements of Wellcome's views are to be found in his evidence to the Royal Commission on Museums and Galleries of 1927. It is the only published source where he expounded on the subject at any length. The Commission was formed to investigate the national museums and art galleries and one of the issues it examined was the founding of a National Ethnographical Museum. Wellcome was called as an expert witness on this question, in view of his huge ethnographical holdings. As he explained, he had "extensive collections that lead up from the very beginning of time, not only prehistoric, but we find traces of disease in the lowest forms of life, continuing right on through the ages, even evidence of the conversion of the inorganic into the organic, and so on ... this medical section has been organised first.... It is my purpose to develop the other sections in due course." 102 Later, he reiterated, "Medicine and its ancillary branches definitely form an essential section of the science of anthropology."103

${ }^{100}$ See the report from P. J. Johnston-Saint, "foreign secretary" of the Wellcome Historical Medical Museum from 1928 until 1934, and then conservator, following Malcolm's departure, until 1947, to Wellcome, 5 June 1936, complaining of Malcolm's previous activities. WI:FC.11c 'To and from W. \& J. S. 1933-1936'.

${ }_{101}$ Typescript, 'Mr. Wellcome's Notes', Washington DC, 31 August 1926, sent to Malcolm. WF:2:DW. 'WHMM 1926'. In fact, Keith chose to speak on the rather more circumscribed topic of 'What should Museums do for us?' This address was printed in the Handbook (1927), pp. 102-110 and the Museums J., 1926-1927, 26: 229-235. The single cell was "the hypothetical starting point for evolution". Lowie, op. cit., note 36 above, p. 23.

${ }_{102}$ Wellcome, Evidence, op. cit., note 1 above, p. 107.

103 Ibid. 
Wellcome's adherence to Pitt-Rivers' injunction that sequence was "the fundamental rule of the game" when dealing with material culture was complete. ${ }^{104}$ "The one thing most desirable in a matter of this kind is to show from the beginning, the evolution and development throughout, the passing on from one stage of progress to another of particular objects ... as far as possible to trace each step from the period of their origin throughout the whole course of development." 105 Indeed, he was unable to contemplate any disruption to universal, progressive sequences. Asked how he would illustrate the substitution of a piece of bottle glass for a flint arrowhead by "the modern savage races" of the Magellan Straits, he unhesitatingly replied "I would put a thing like that down as a freak." ${ }^{106} \mathrm{He}$ also made clear the rather limited role which he accorded to archaeological material. It seems he regarded it very much as a "prop" for anthropology, to be resorted to for filling in the early parts of object sequences but with a subservient role to anthropology in elucidating history. "Archaeology is practically in a different field", he told the Commission, who were surprised to hear that he would not advocate incorporating the British Museum's Stone Age collections in any proposed national ethnographical museum. "Archaeology mainly represents the higher cultures of antiquity. In the Historical Medical Museum anthropology represents the more primitive life from the earliest periods and traces the developments up to the present day." ${ }^{107}$ Here Wellcome demonstrates that overriding concern with retrieving the most primitive origins that characterized evolutionist methods. The "higher cultures of antiquity" had already "advanced" too far.

Anxious to determine whether a national ethnographical museum should be created, the Commission pressed Wellcome on the matter of public access. "The question ... requires careful consideration", he felt, "A great many people visit museums simply as stragglers." 108 A confusing discussion ensued with Wellcome describing an ideal museum of two, or possibly three sections involving an educational research department, where laboratories were the "special features" and the promotion of "scientific research" on each branch of anthropology represented "one of its first aims". "Intellectual people", "those genuinely concerned and interested in the subjects represented there who attend entirely for beneficial information" might be admitted to a "Museum devoted to research purposes" such as he envisaged. This would be unlike most other museums, which were "arranged for popular entertainment, to gratify those who wish to view strange and curious objects". ${ }^{109}$ The Committee soon abandoned this line of enquiry, perhaps rightly concluding that the concerns of the general public were not uppermost in Wellcome's mind. His Historical Medical Museum seems not, in his lifetime, to have been open to the general public without prior written application, and certainly no effort was made to attract non-specialist visitors or children. Overall attendance figures, which are occasionally mentioned in conservators' reports, were, not surprisingly, low. In June 1926, for

\footnotetext{
104 "Progress is like a game of dominoes . . the fundamental rule of the game is sequence." A. H. L. Fox (Pitt-Rivers) 'Principles of Classification', quoted in Thompson, op. cit, note 49 above, p. 40.

105 Wellcome, Evidence, op. cit., note 1 above, p. 107.

106 Ibid.

107 Ibid., p. 108.

108 Ibid., p. 107.

109 Ibid.
} 


\section{Sir Henry Wellcome's museum for the science of history}

example, there were 104 visitors. This was apparently the largest figure for that month since $1919 . .^{110}$

One group of visitors for which Wellcome was prepared to cater were those guardians of the Empire whose duties brought them into contact with the "subject native races": "Colonial and military officials, explorers, colonizers, planters, missionaries-would find it invaluable". ${ }^{111}$ The usefulness of anthropology to colonial administrators in understanding the "habits, customs, superstitions, beliefs, fears and prejudices of the subject native races" was frequently alluded to by those who wished to promote the discipline in the late nineteenth and early twentieth centuries. ${ }^{112}$ The Commission was not unimpressed by the point, making much of "the great part which an adequate Ethnographical Collection could play in satisfying Imperial and economic needs". ${ }^{113}$ Wellcome's evidence on this topic was quoted at length in their final report. In notes prepared before he gave oral evidence, Wellcome had described such a Museum as "the laboratory where cultural and technological problems would be solved", perhaps echoing, nearly sixty years later, Tylor's famous conclusion that "the science of culture is essentially a reformer's science". ${ }^{114}$

III

If it is accepted that Wellcome saw the history of medicine as a part of anthropology, then the collection which he amassed, and the methods he used to acquire it, appear less extraordinary. The latter bear a close resemblance to those used by late nineteenthcentury anthropologists. Amateur collecting (in Wellcome's case, by paid agents, missionaries, and museum employees) had perfectly respectable precedents. Many large ethnographic collections were built up in the nineteenth century through the activities of colonial administrators, missionaries, and other travellers, and often involved commercial considerations. ${ }^{115}$ Professional anthropologists regarded their contributions as important. Far from censuring such activities, they attempted to

110 The 1913 exhibition, held in conjunction with an International Medical Congress, had been "not intended for the general public, but members of the medical profession, chemists, scientists and nurses in uniform will be admitted". Br. med. J., 1913, i: 1379. For correspondence indicative of entry regulations, see WI:FC:10D 'WHMM Visitors and Parties, 1913-1921' and 'WHMM invitations and admissions to Museum'. For attendance figures, see for example, various Reports, Malcolm to Wellcome, WF:E2:DW 'WHMM 1926', and 14 April 1927, WF:E2:DW 'WHMM 1927'.

${ }_{111}$ Wellcome Evidence, op. cit., note 1 above, p. 103.

112 See, for example, A. C. Haddon, Presidential address, 'Anthropology, its position and needs', J. $R$. Anthrop. Inst., 1903, 33: 19-20. "The public ... must be made to see that efficiency and economy . . . are the practical results of a sympathetic study of those peoples; that, in fact, ... it "pays' to study Ethnology".

${ }_{113}$ Great Britain, Royal Commission on National Museums and Galleries, Final Report, Part I, London, HMSO, 1929, p.59.

${ }^{114}$ From Wellcome's answers to a questionnaire apparently in preparation for his evidence to the Royal Commission, W.F:E2:DW 'WHMM, 1927' p. 39. Tylor's conclusion formed the closing sentence of Primitive culture, Tylor, op. cit., note 41 above, p. 453.

${ }^{115}$ For a survey of field work in British anthropology from Tylor to Malinowski, including the role of amateur collectors and informers, see George W. Stocking jun., 'The ethnographer's magic' in George W. Stocking jun. (editor) Observers observed. Essays on ethnographic fieldwork. Madison, University of Wisconsin Press, 1983. For listings of early collectors, see H. J. Braunholtz, Presidential Address, 'Ethnographical museums and the collector: aims and methods, J. R. Anthrop. Inst., 1983 68: 7, 8. For a circular sent by Wellcome to missionaries, appealing for objects, n.d. but prior to 1911, see WI:FC.9A 'WHMM Notices \& Circulars 1913 exhibition'. 


\section{Ghislaine M. Skinner}

maximize their usefulness by providing basic guidance for such untrained collectors. Section D of the British Association for the Advancement of Science compiled its Notes and queries on anthropology for the use of travellers and residents in uncivilized lands in 1874. ${ }^{116}$ An aide-mémoire, it gave instructions on what questions to ask and what objects to collect. The 1912 edition showed considerable revision of the "Tylorian" stance that had characterized earlier ones. A decade later, when anthropology had achieved full section status in the British Association, their Committee set up to investigate the North-Western Tribes of the Dominion of Canada began by preparing a Circular of enquiry for the use of government officers, missionaries, travellers, and others. ${ }^{117}$ In 1887, Sir James Frazer had privately printed Questions on the customs, beliefs and languages of savages to facilitate research on The Golden Bough. ${ }^{118}$

During the late 1920s, the Wellcome Historical Medical Museum produced a booklet which closely resembled Notes and queries. Entitled Memoranda concerning the collection of information and material among primitive peoples, it was also designed for travellers, being pocket-sized and containing lists of questions to be asked under a series of headings - deities, medicine men, disease, superstitions, poisons, family life and marriage, childbirth, burial, astrology, artistic workmanship, weapons, and currency. ${ }^{119} \mathrm{~A}$ limited number of possible answers was suggested. Was marriage, for example, "by capture, exchange or purchase"? The origins of certain practices were explicitly to be sought-“"Is any method of inoculation known?" and "Is bleeding, scarifying or cupping practised?" were the second and third of thirteen questions on medical treatment. There appears to be no record of how many Memoranda were distributed or completed. Several hundred unused copies remain in the archives. By the 1920 s, when anthropologists had ventured into the field themselves, this method was old fashioned, but it had been an accepted one during the decades when anthropologists constructed theories at home, largely dependent on data collected by others. Like them, Wellcome considered collecting of major importance. He held it to be the prime function of the Wellcome Historical Medical Museum. ${ }^{120}$ Neither exhibitions nor cataloguing were high priorities, and Wellcome was generally unreceptive of suggestions from the conservators that staff be engaged on sorting and identifying rather than collecting. ${ }^{121}$ So long as sufficient data (in this case material

${ }^{116}$ British Association for the Advancement of Science, Notes and queries on anthropology, for the use of travellers and residents in uncivilized lands, London, 1874.

117 Stocking, op. cit., note 115 above, p. 72.

118 Ibid., p. 75.

119 Memoranda concerning the collection of information and material among primitive peoples, WHMM, [n.d. but probably c. 1927]. See Malcolm's notes of tasks to be completed June and July 1926. W.I. Correspondence Files, 1926, 'M'.

${ }^{120}$ See letter, Wellcome to Malcolm, WF:E2:DW, 'WHMM 1926': “The main function of the museum is to acquire material".

121 See, for example, Report, Thompson to Wellcome, 5 January 1909. WI:FC:9A. The intensive nature of the Museum's collecting activities is striking, Thompson's reports consisting largely of details of acquisitions made. Circulars were sent to the "eighteen oldest hospitals in the country", seeking material (Report, Thompson to Wellcome, 31 August 1917. WI:FC:9A). Advertisements were placed in Bazaar Exchange and Mart (WF:E2:DW. 'WHMM 1927'). The sculptor Epstein was persuaded to try and borrow back statuary given to friends, in order that the Museum might make models (Report, Thompson to Wellcome, 2 Dec 1905. W.I:FC: 9A). 
culture) was gathered together, "scientific" researchers would construct their theories from it at a later date.

In many other ways, the activities of the Wellcome Historical Medical Museum reveal an indebtedness to anthropology. The enormously wide range of items collected gave rise to subsequent speculation that Wellcome intended to create an additional ethnographical museum, and some of his public utterances support this view. ${ }^{122}$ However, the firm distinction between "medical" and "ethnographic" objects is largely one imposed by later writers. It was not one which Wellcome made easily, and was certainly not one made in the museum's everyday activities, as revealed by the conservators' reports. Wellcome admitted that his "collections of anthropological material, considered as such, are vastly greater than the strictly medical". ${ }^{23}$ But it seems he shared the biologized definition of medicine still current amongst some anthropologists. As a Fellow of the Royal Anthropological Institute put it when they met at the Museum in 1927, "The distinctive attribute of all living creatures is the preservation of life, and the great majority of the activities of all living creatures are concerned unwittingly with this process. When man first became rational he attempted by the use of his reason to devise means of protecting his life from extinction." "The great central aim of this Museum is to illustrate the motive that underlies all these collections of objects." 124 Viewed in this light, as the result of an instinct for self-preservation, the practice of medicine was equated with the preservation of health and was hard to disentangle from the provision of food, a mate, and protection from the elements and enemies. The 1913 exhibition was to include "ancient methods of grinding corn, baking and cooking", "curious articles of food and culinary implements", and "historic menu cards". ${ }^{125}$ A display of weaponry was a prominent feature of the Museum from 1916 onwards. Material relating to criminology had always featured, such as "improvised instruments used for criminal purposes" and "curious methods of torture and execution" (plate 5). ${ }^{126}$ A whole section on 'Adulteration and falsification of drugs, medicines, foodstuffs, fabrics and of any articles affecting health', was planned. ${ }^{127}$ In this biological account it was possible to find a "medical" role for almost all of the object categories that Wellcome collected, since all could increase or diminish man's wellbeing-as Wellcome put it, "most . . . anthropological material possesses strong medical significance, for in all the ages the preservation of life and health has been uppermost in the minds of living beings". 128 "Medical" artefacts were "anthropological", and "anthropological" or "ethnographic" artefacts almost always possessed medical significance.

\footnotetext{
122 See, for example, Wellcome, Evidence, op. cit., note 1 above, p. 107. But see Haggis, op. cit., note 11 above, for Pearson's comment.

123 Ibid., p. 108. He told the Commission that his "interest in anthropology came before the medical but still they have both continued on parellel lines or have been merged".

${ }^{124} \mathrm{G}$. Elliot Smith in Wellcome Historical Medical Museum. Reception to Members of the Royal Anthropological Institute, 24 May, 1927. p2.Typescript WF: E2:DW. 'WHMM, 1927'. See also Handbook (1920), p.9: "In primitive medicine we have the first instincts of man towards the relief of pain and cure of disease."

125 Op. cit. (c. 1911), note 77 above, p. 13.

126 Ibid., and Handbook (1927), p. 71.

127 Op. cit. (1903-4), note 77 above, 'Section 12'

128 Wellcome, Evidence, op. cit., note 1 above, p. 108.
} 


\section{Ghislaine M. Skinner}

Large parts of the collection, including what might be termed "works of art", from literate, "higher" cultures lacked any great aesthetic or monetary value. Relatively few would be accepted by museums of fine arts. Wellcome was not stinting with financial provision for the Museum-he spent an estimated $£ 400,000$ in all on the Museum and Library - but it is noticeable that he left alone the top end of the antiques market. ${ }^{129} \mathrm{At}$ the Hope sale of classical sculpture in 1917, for example, the Museum was not even in the running for a statue of Hygeia which fetched 4,000 guineas, and was not prepared to go above 1,700 guineas for one of Asklepios, but was content to have a replica made. ${ }^{130}$ It was the underbidder for several "middle-range" items and successfully acquired some less expensive items at the sale. Perhaps bearing in mind Pitt-Rivers' injunction to "collect the everyday", it seems that in many ways Wellcome applied the same criteria to the collection of the material culture of literate, more recent societies as he did to that of primitive or ancient ones. Concerned to illustrate changes in the external morphology of objects, or the content of representational art, up to recent times, it is as though antique shops and auction houses, market stalls, the columns of Exchange and Mart, and indeed existing museums were to him as much a part of "the field" as were the jungles of Borneo or the African interior. They were to be scoured for objects in a similar way. As with ethnographic objects, information about their age, function, or place of origin was recorded if available, but the absence of such details was certainly not a contraindication to acquisition, since, provided enough had been collected, the accurate position of each could subsequently be detected within an absolute progressive sequence-as the archaeologists were able to do. "A stray fragment of carving without date or locality can be surely fixed in its place if there is any sufficient knowledge of the art from which it springs", as Flinders Petrie told the anthropological section of the British Association for the Advancement of Science in 1895. ${ }^{131}$ A very large part of Wellcome's collections lacked any provenance at all and many items, although of antique form and design, are of relatively recent date. Soon, only estimates of the holdings were available. "The more you can complete the various series of ethnographical objects, the more effectually the collections will visualize and demonstrate the characteristic features; thus you would be able to trace the evolution from $A$ to $Z$ in the development of any particular branch."132 The collections of the Pitt-Rivers Museum, assembled on a similar basis, became as large as Wellcome's. ${ }^{133}$ The evolutionists were committed to dealing with huge amounts of data, whether material or otherwise, not only for the reconstruction of complete sequences and the detection of the general trends and similarities on which a science of universal history depended, but to minimize error. Tylor, Morgan, and Spencer all hoped to balance out the effects of unreliable data by examining sufficient instances. ${ }^{134}$ Further impetus to

\footnotetext{
129 Turner, op. cit., note 9 above, p. 41.

130 For an account of the museum's strategy at this sale, see the addendum (25 July 1917) to Report, Thompson to Wellcome, 13 July 1917 (WI:FC:9A). They had put a limit of 700 guineas on the Hygeia, and 1,400 guineas on the Asklepios, though Thompson "ran up" the successful bidder, Gordon Selfridge, to 1,700 guineas for Asklepios.

131 Flinders Petrie, quoted in A. C. Haddon, Evolution in art, London, Walter Scott, 1895, p. 336.

132 Wellcome, Evidence, op. cit., note 1 above, p. 105.

133 Blackwood, op. cit., note 49 above, p. 11.

134 Harris, op. cit., note 36 above, p. 156.
} 
collect came from the fear that the data was fast vanishing. Folklorists warned that the "footprints in the sands of time" which they sought to record were "fast being trampled out by the hurrying feet of the busy multitudes of the present". ${ }^{135}$ The changes induced in "primitive" societies by the proximity of "civilized" ones-later to be areas of intense interest to anthropologists-were dreaded by many at the turn of the century, since they obscured the distant origins of culture they sought to recover. ${ }^{136}$

In its exhibition galleries, it is striking that the Museum made no attempt to incorporate the chronology of written history, and made only perfunctory reference to its content. No use was made, for example, of organizing principles such as the Renaissance or the Enlightenment. This sacrificing of chronicled events to the "grand scheme of comparative reconstruction" was precisely the fault which Franz Boas (1858-1942) and the accidentalist school were to perceive in the evolutionist anthropology they did much to discredit. ${ }^{137}$ The Museum's total lack of an overall chronological arrangement, apart from the obligatory beginning in the Hall of Primitive Medicine, was entirely consistent with the evolutionist approach-as was the use of reconstructed room settings. These were the only areas where different types of object of similar date were displayed together and this was done quite separately from the main galleries, with which there was no attempt to integrate them.

The museum displays also made quite extensive use of replicas, Wellcome being content to commission these in place of expensive or unobtainable objects. Current museum practice, with its reverence for original objects, in many instances finds this hard to accept, but the practice of replica-commissioning was not unusual in late nineteenth- and early twentieth-century museums. The second of the subjects to which the newly founded Museums Association intended to give attention in 1888 was "Means of securing models, casts and reproductions". ${ }^{138}$ The popular American Handbook for small museums by L. V. Coleman, published in 1924, gave as an appendix the names of "reputable replica producers". ${ }^{139}$ For Wellcome's purposes a replica which could illustrate some sequential continuity was perhaps more useful than an unobtainable original. Representational art lent itself even more readily to reproduction, and Wellcome used contemporary artists, including one known as "Hayman the faker", to copy drawings and paintings with a "medical" content. ${ }^{140}$ Others, who specialized in the genre of historical reconstruction, were commissioned to produce paintings of particular events where none existed. The scenes selected were

135 Charlotte Burne, 'The collection of English folklore', Folklore, 1890, 330.

136 See, for example, A. C. Haddon, 'The saving of vanishing data', Popular Science Monthly, 1903, 62: 222-229. After much analogy with the naturalists' problem of extinct flora and fauna, Haddon urged immediate steps to record anthropological data in islands where "the natives have become so modified by contact with the white man ...". Characteristically, however, he goes on to warn against the untrained observer, and the rapid collector, who "does positive harm, as, like the unskilled excavator, he destroys the collateral evidence". See also similar warnings in W. H. R. Rivers, 'Report on anthropological research outside America', in Reports upon the present condition and future needs of the science of anthropology, Washington, DC, Carnegie Institution, 1913.

137 Voget, 'Man and culture', op. cit., note 43 above, p. 347.

138 'The Museums Association and its journal', Museums J., 1901-2, 1: 5.

139 L. V. Coleman, Manual for small museums, New York and London, G. P. Putnam's Sons, 1927.

140 For dealings with "Hayman the faker" see the extracts from Thompson's reports for 14 June, 19 July, and 11 August 1916 in 'W.H.M.M. Records'-a bound typescript of extracts from early WHMM papers prepared by A. L. Dean, retired Museum secretary, from 1956-1959. Original reports for these dates are lost. 
often those for which there was little documented evidence. ${ }^{141}$ Wellcome seems almost to have been seeking a pictorial record of the mythology of Western Medicine to the present time. In similar vein, he fostered a cult of the eminent physician, going to great lengths to secure the academic robes of Sir William Osler (1849-1919) and many others, displaying personalia such as surgery door plates and knobs and devoting a whole display case to "doctors' walking sticks and canes", much in the same way that he exhibited the bones and rattles of medicine men and shamans. ${ }^{142}$ By and large, however, Wellcome's intense concern for the primitive led to a relative disregard for the contemporary, a trait which Burrow and others found characteristic of evolutionist anthropologists. ${ }^{143}$ The Wellcome Historical Medical Museum ostensibly covered the history of medicine from prehistoric times to the present day, after which the Wellcome Museum of Medical Science "continued the story". ${ }^{144}$ Soon after Malcolm's appointment, he mistakenly referred to this museum as the "Museum of Modern Medicine". ${ }^{145}$ Wellcome corrected him but, for both men, in some sense, "medical science" was "modern medicine". If, for Charles Singer (1876-1960) and his colleagues, there was a caesura in medicine somewhere about $500 \mathrm{BC}$, for Wellcome it was located roughly in the 1880 s and had to do with laboratory science. ${ }^{146}$ As founder of the country's first physiological and pharmacological research laboratories, he was in a prime position to collect the equipment used in them. However, not even an association with notable discoveries or famous men tempted him to acquisition. The collection apparently contains no apparatus at all from the Wellcome research laboratories and only about five per cent of the "non-ethnographic" items were twentieth-century, a tiny proportion of these being laboratory apparatus. In at least one instance the Museum considered selling modern instruments acquired as part of job lots. ${ }^{147}$ Modern material that might shed light on origins, however, was acquired.

141 Of a series of thirty oil paintings shown at the 1913 exhibition, twenty were prepared by Ernest Board (1877-1934), an artist who specialized in historical reconstruction. They included subjects such as 'Galen studying the anatomy of the body' and 'Discovery of the stethoscope, 1815'.

142 Handbook (1927), p. 55. Osler's 'Edinburgh cap and gown' were recorded as "promised" by Lady Osler in 1926. See ' $L$ ist of donors and the material given to the W.H.M.M. during the year 1926'. Typescript. W.F.E2.DW. 'WHMM, 1926'-Arthur Keith observed that "the counterparts of the native artillery" (displayed in Wellcome's Hall of Primitive Medicine) "in Harley Street are the stethoscope, the bismuth meal, notebook for prescription and a certain professional air." Keith, quoted in F. H. Garrison, "A medical tour in Europe', Bull. N. Y. Acad. Med., 1930, 6: 243-264, reprinted in F. H. Garrison, Contributions to the history of medicine, New York, Hafner, 1966, pp. 649-655.

143 Burrow, op. cit., note 16 above, p. 244. For further evidence of Wellcome's intense concern with primitive material, see his letter to Malcolm, op. cit., note 13 above. In full the passage reads: "I explained to you explicitly what I wanted first of all-all my ethnological, anthropological, archaeological and all other primitive material sorted out, classified, prepared, numbered and catalogued. Also, I gave you definite instructions that these materials must be sorted, classified and grouped scientifically so as to faciliate the final arrangement of materials in the prehistoric and primitive halls. Furthermore, I told you that I would personally supervise and direct the arrangement of these exhibits and decide the methods of display of all the aforementioned materials."

144 The formation of a didactic museum of tropical medicine and hygiene was proposed by Andrew Balfour, director of Wellcome's research laboratories in Khartoum from 1902 to 1912 . Founded in 1914, it was expanded and renamed in 1924 at a formal opening of the Bureau for Scientific Research. See, The Wellcome Museum of Medical Science 1914-1964, London, Wellcome Foundation, 1964.

145 Letter, Malcolm to Wellcome, op. cit., note 64 above, p. 2.

146 Charles Singer, A short history of medicine, Oxford, Clarendon Press, 1928, p. 1.

${ }^{147}$ Report, Thompson to Wellcome, 4 January 1907. WI:FC:9A. 
In 1915, for example, the Museum accepted a collection of charms removed from the bodies of fallen German soldiers, via the Folklore Society. ${ }^{148}$

Malcolm's appointment in 1925 brought the Museum, initially, some contact with academic anthropology. He reported that the elderly Sir James Frazer wished to visit together with Baldwin Spencer (1860-1929), his long-time correspondent on the aboriginal races of Australia, in 1927. ${ }^{149}$ Medical men came too, of course, and medical societies and congresses found a visit to the Museum a congenial addition to their programmes, but it was anthropologists who, for a short time, seemed to view it as a potential scholarly resource. Informal approaches were made by $W$. J. Perry (1887-1949) of University College to see if the Museum's collections might be used for his postgraduate research students. ${ }^{150}$ From Cambridge, Haddon sought financial support for "a very keen student who is working hard and will do well"-L. S. B. Leakey (1903-72). ${ }^{151}$

The most prestigious approach came in 1927, when Haddon himself, through his former student Malcolm, offered his services to the Museum. Retiring from his readership at Cambridge, Haddon was "prepared to act as an advisor in Ethnology". 152 Haddon has been identified as the first of a new breed of anthropologist, a natural scientist who applied the observational methods in which he was trained to anthropology. ${ }^{153}$ A protégé of Michael Foster (1836-1907) at Cambridge, Haddon came to prominence after leading the Torres Straits expeditions of 1888-9 and 1898-9, orginally with the "archetypically Darwinian" scientific goals of producing a comprehensive survey of the island's geology, flora, fauna, and native peoples. His interests turned increasingly to ethnology, and the second expedition, now seen as a landmark in the development of anthropological fieldwork, concentrated exclusively on this. Largely on the strength of the Torres Straits work, Haddon was awarded the newly created readership in anthropology at Cambridge (though not until 1909). He has been seen as marking, in Britain, the transition which anthropologists made "out of the armchair into the field" - or at least on to the verandah. 154 Subsequently, collection of data in the field, by trained observers active within the discipline and contributing to its theory, became the model for fieldwork and fieldwork became constitutive for anthropology. Theorizing at home on the basis of material collected by amateurs, however well directed by Notes and queries or the like, came to be

\footnotetext{
148 Report Thompson to Wellcome, 5 February 1915. WI:FC:9A.

149 Malcolm, Report to Wellcome, 5 July 1927. WF:E2:DW. 'WHMM, 1927'. A few months earlier, Malcolm had suggested Sir James Frazer as a suitable person to address the Royal Anthropological Institute when it met in the Museum in May 1927. In fact, G. Elliot Smith addressed the meeting. See note 124 above.

${ }_{150}$ Report Malcolm to Wellcome, 16 March 1926, WF:E2:DW. 'WHMM 1926'.

151 Report Malcolm to Wellcome, 28 February 1926. WF:E2:DW. 'WHMM, 1926'.

152 Report, Malcolm to Wellcome, 26 January 1926. WF:E2:DW. 'WHMM 1926'. Haddon had been appointed to a similar post at the Horniman Museum in London in 1901. Van Keuren, op. cit., note 54 above, p. 195.

${ }^{153}$ The only biography of Haddon remains A. H. Quiggin, Haddon the head-hunter, Cambridge University Press, 1942, but for assessments of his contribution to anthropology see Stocking, op. cit., note 115 above, pp. 75-85; and Meyer Fortes, 'Social anthropology at Cambridge since 1900', in Darnell (editor), op. cit., note 43 above, pp. $426-439$.

is4 Gerald L. Geison, Michael Foster and the Cambridge school of physiology, Princeton, New Jersey, Princeton University Press, 1978, pp. 5 and 119. Stocking, op. cit., note 115 above, p. 75. It seems Haddon introduced the term "fieldwork" into British anthropology (ibid., p. 80).
} 


\section{Ghislaine M. Skinner}

regarded as inadequate. Haddon's "intensive study of limited areas" set new standards within the discipline. He led what came to be known as the Cambridge school, of which W. H. R. Rivers, early in his career, was a prominent member.

Haddon had not, however, lost the traditional interest in material culture-indeed Stocking identifies it as his "most systematic ethnological concern". $155 \mathrm{He}$ expanded the collections of the Cambridge University Museum of Archaeology and Ethnology to establish artefact typologies, and made an early attempt to study the evolution of decorative design. ${ }^{156}$ Although considered instrumental in defining modern anthropological fieldwork, Haddon also relied on "ethnography by mail", though he chose his informants with care. ${ }^{157}$ In many ways he was a transitional figure between the old and the new in anthropology. Aware, as he put it in his brief History of anthropology (1910), that "the comparative method is liable to lead the unwary into mistakes", that "the chief danger to which [anthropology] is liable is that its fascination and popularity...tend to premature generalisations", and of the "promising" methods of the French sociologists, he might have preserved the Museum from an approach that was becoming distinctly old-fashioned, had Wellcome accepted his offer. ${ }^{158}$

Although the Wellcome Historical Medical Museum aspired to "scientific" anthropology, it was, by the late 1920 s, increasingly out of touch with development in the academic discipline. The tide was turning slowly but inexorably away from the study of material culture, this being firmly (though not necessarily) associated with the increasingly discredited evolutionist school. ${ }^{159}$ As early as the mid-1890s, a sense of crisis had been evident in evolutionary theory in Britain, and, by 1910, "the theoretical malaise... was becoming acute". ${ }^{160}$ In the United States, Franz Boas, finding anthropology "a happy hunting ground for the romantic lover of primitive things" was to leave it radically changed by his criticism of the comparative method and insistence on exhaustive field work. ${ }^{161}$ Committed to a belief in the essential uninventiveness of man, Boas and the diffusionists did find a role for historical explanation and for material culture studies that provided evidence for the diffusion of culture traits. Boas took issue with the curator Otis T. Mason (1838-1908) in 1887 for using Pitt-Rivers' classification system at the American Museum of Natural History. Together, they rearranged the collections using the "culture area" concept. ${ }^{162}$ In Germany,

155 Stocking, op. cit., note 155 above, p. 75.

156 Haddon, op. cit., note 131 above. On his collecting for the Cambridge Museum, see Ebin and Swallow, op. cit., note 56 above, pp. 17-24.

157 Stocking, op. cit., note 115 above, p. 77.

158 Haddon, op. cit., note 36 above, pp. 153, 154, 143.

159 David Miller, Editorial, 'Things ain't what they used to be', Royal Anthropol. Inst. News., Dec. 1983, 59: 5 .

160 Stocking, op. cit., note 115 above, pp. 91 and 94

161 Ruth Benedict, Obituary of Franz Boas, Science, 1943, 97: 60-62, quoted in Harris, op. cit., note 36 above, p. 253. On the extremely influential role of Boas in shaping anthropological theory and practice at the turn of the century, particularly in the United States, there are numerous sources. For an interpretive anthology of a broad range of Boas' writings, see George W. Stocking jun. (editor), A Franz Boas reader. The shaping of American anthropology 1883-1911, University of Chicago Press, 1974.

162 Schlereth, op. cit., note 7 above, p. 12; and Harris, op. cit., note 36 above, p. 374. Boas' criticisms were contained in two articles: 'The occurence of similar inventions in areas widely apart', and 'Museums of ethnology and their classification' in Science, 1887, 9: 485-486, 587-589. 


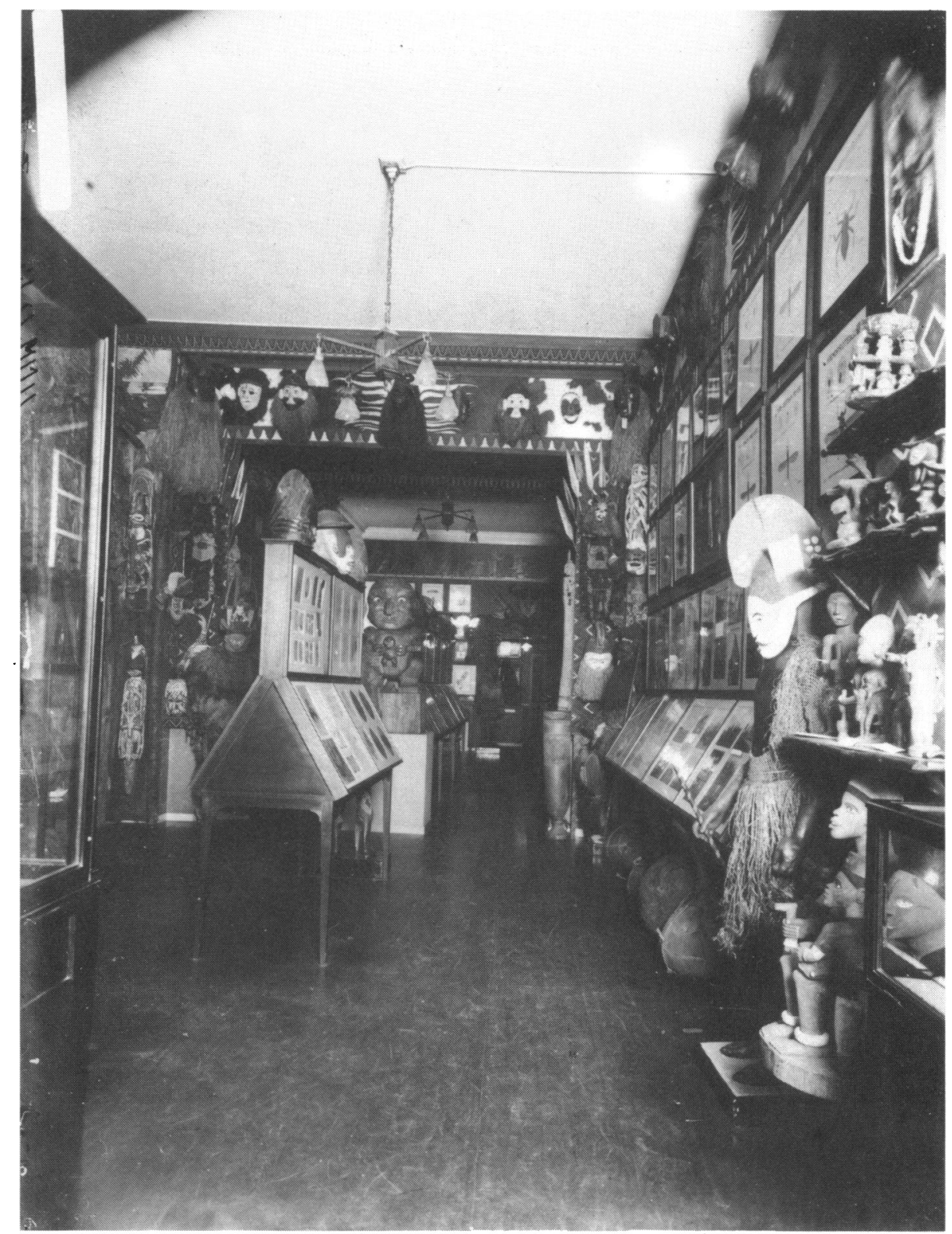

Plate 1 Hall of Primitive Medicine, Wellcome Historical Medical Museum (13 Wigmore Street), c. 1914. (Plates 1-5, Wellcome Institute Library, London.) 


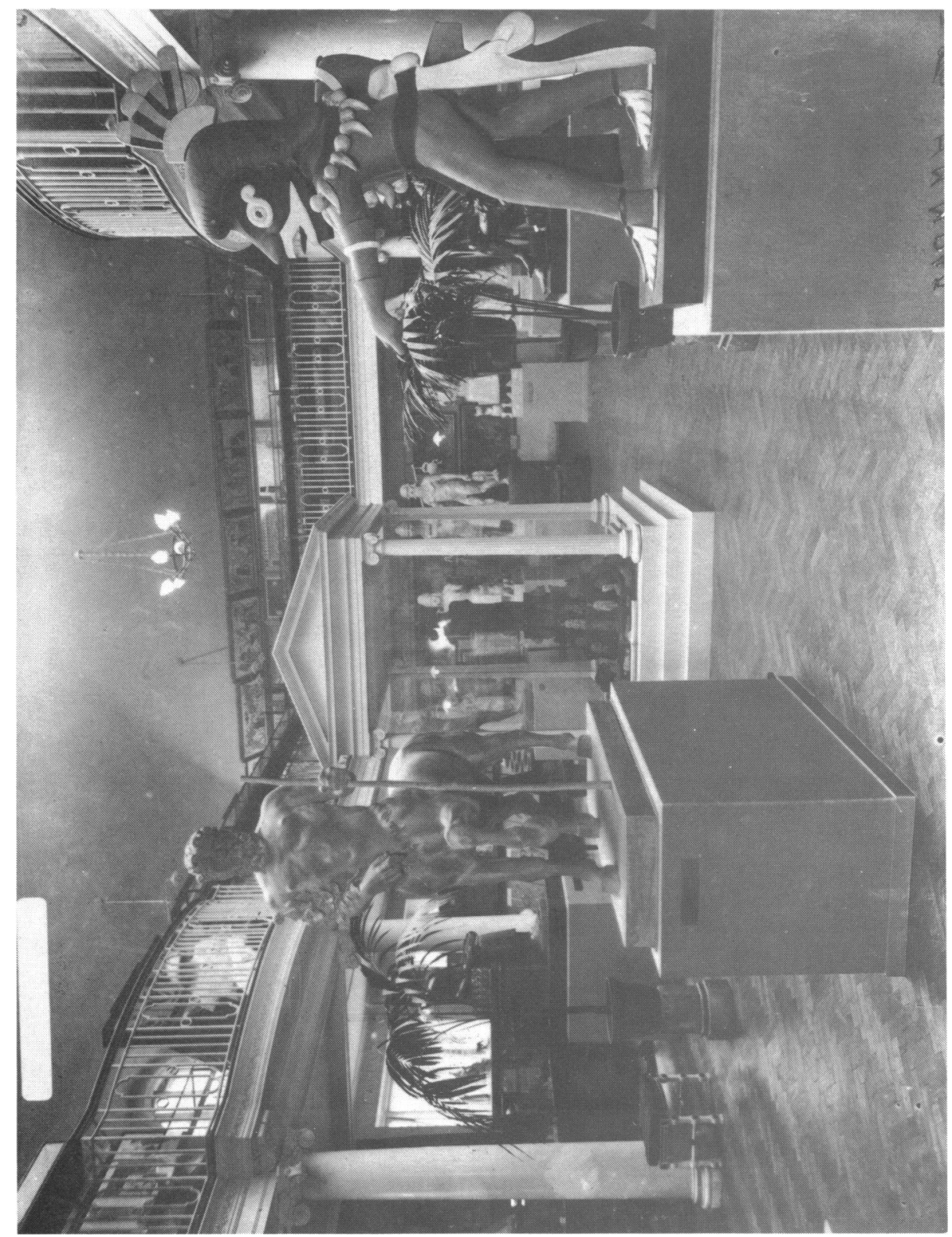

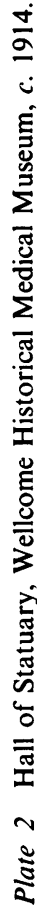




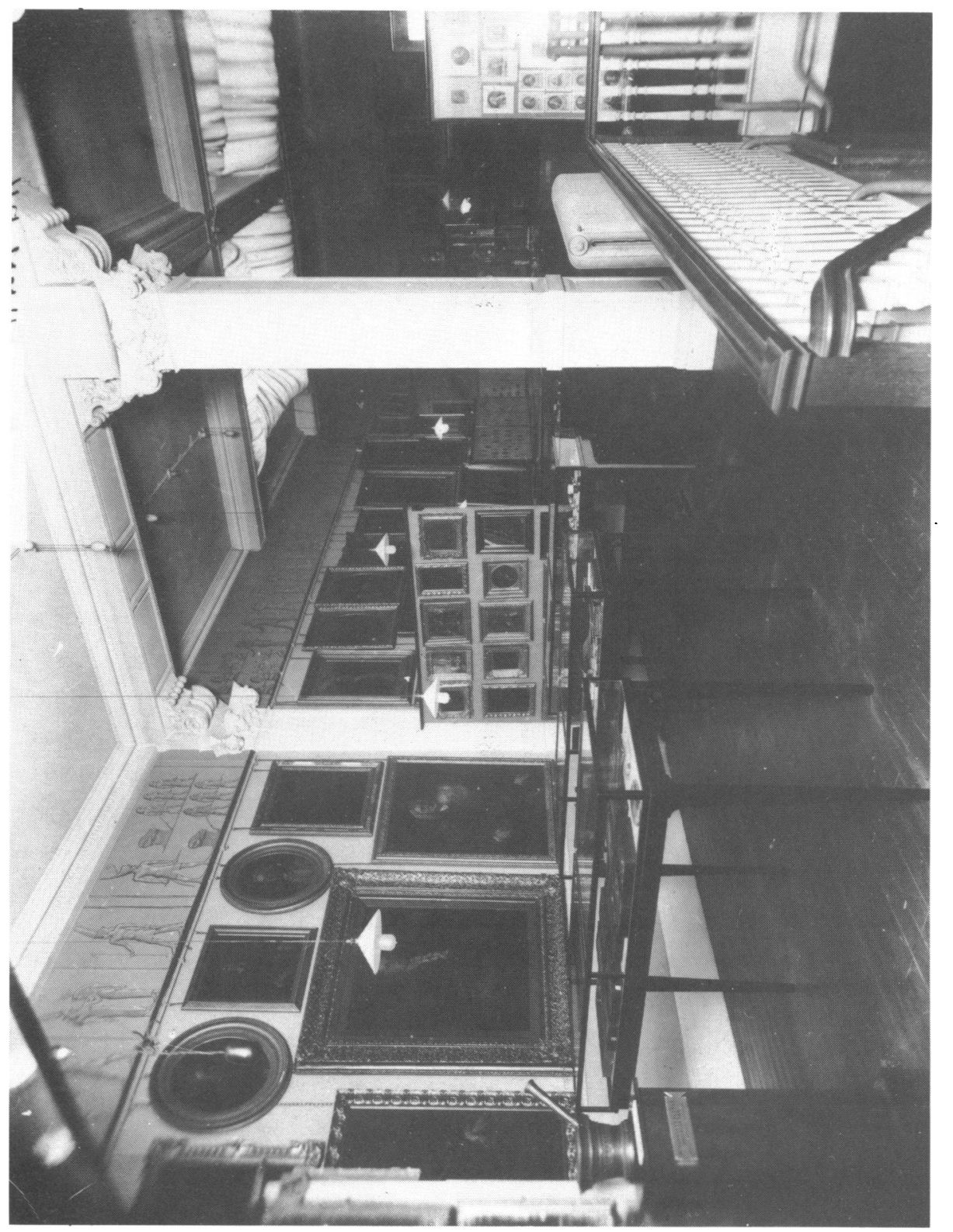

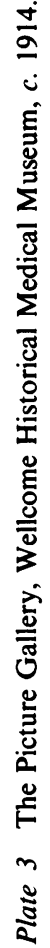




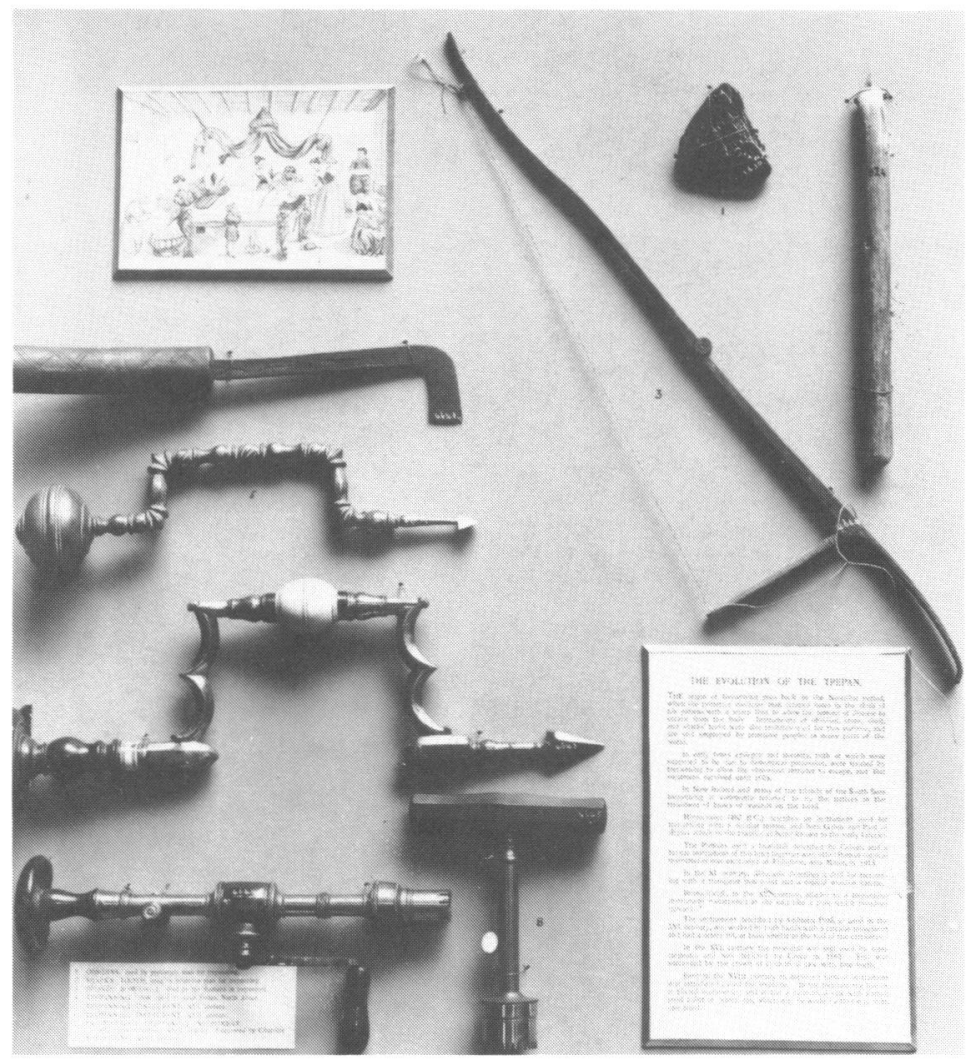

(a)

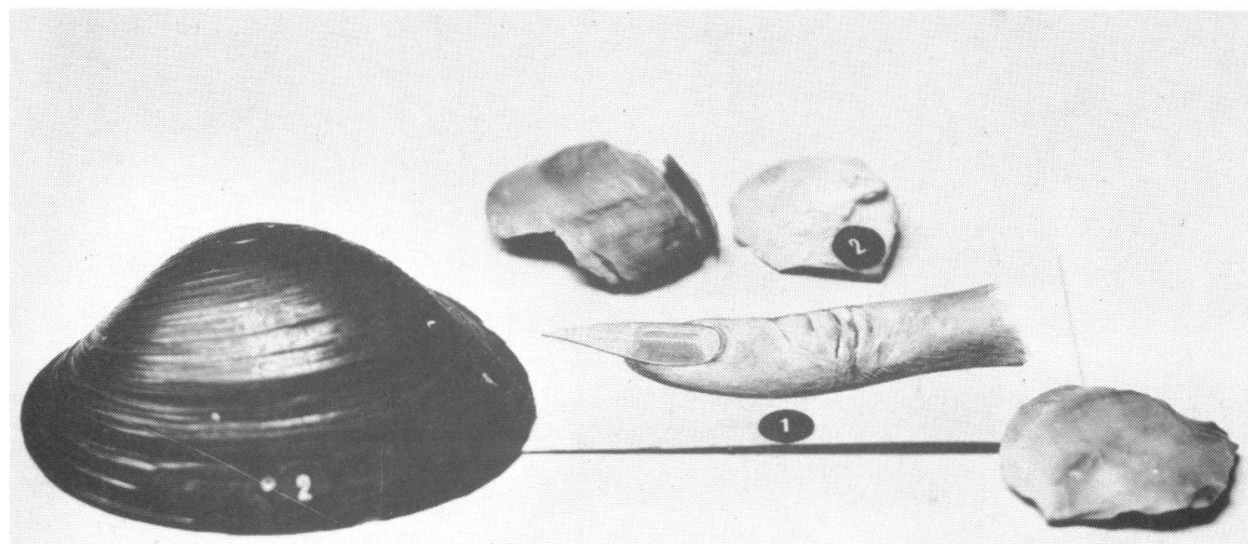

(b)

Plate 4 Displays from the Wellcome Historical Medical Museum to show the evolution of (a) the trepan and (b) the lancet, c. 1927. 


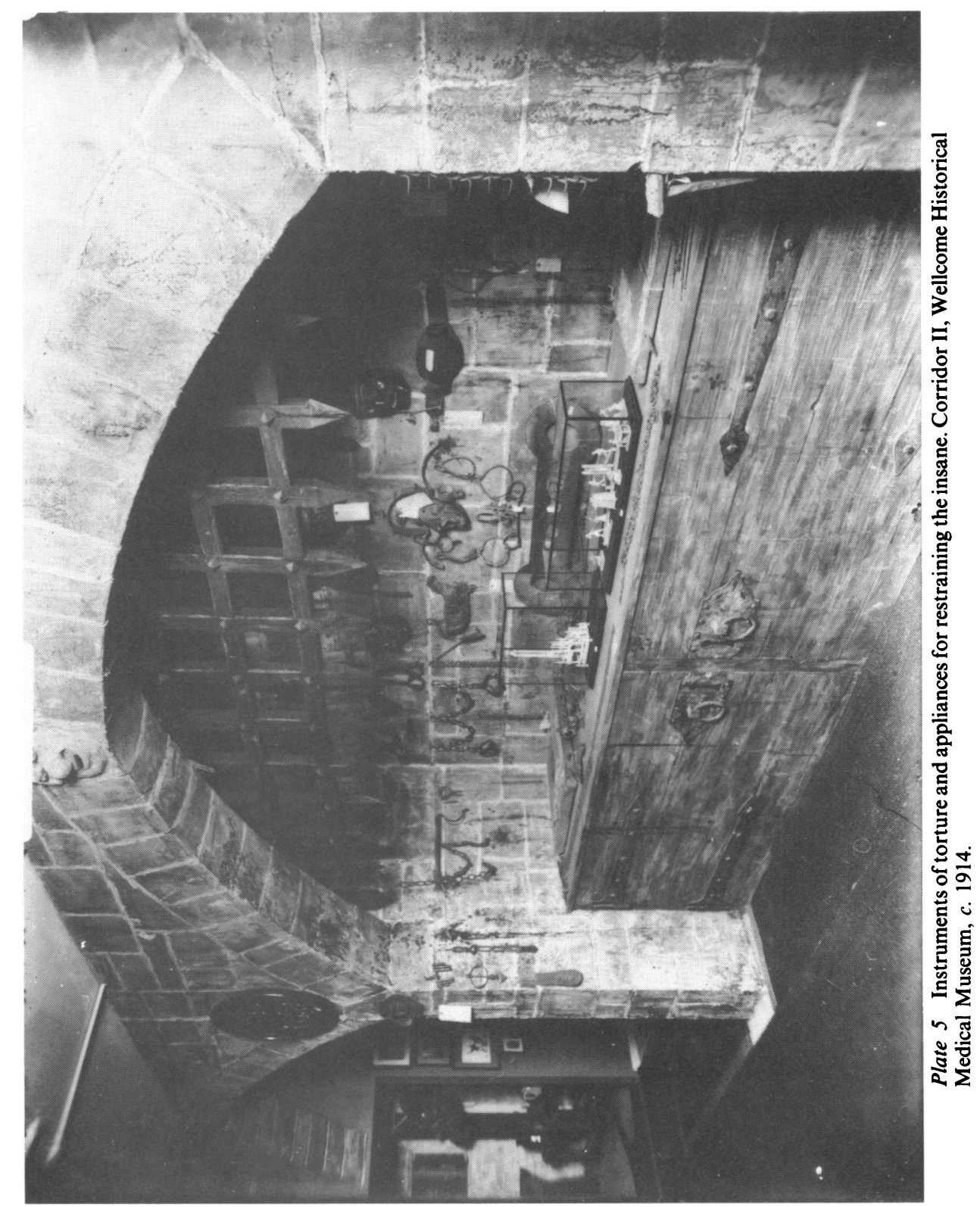




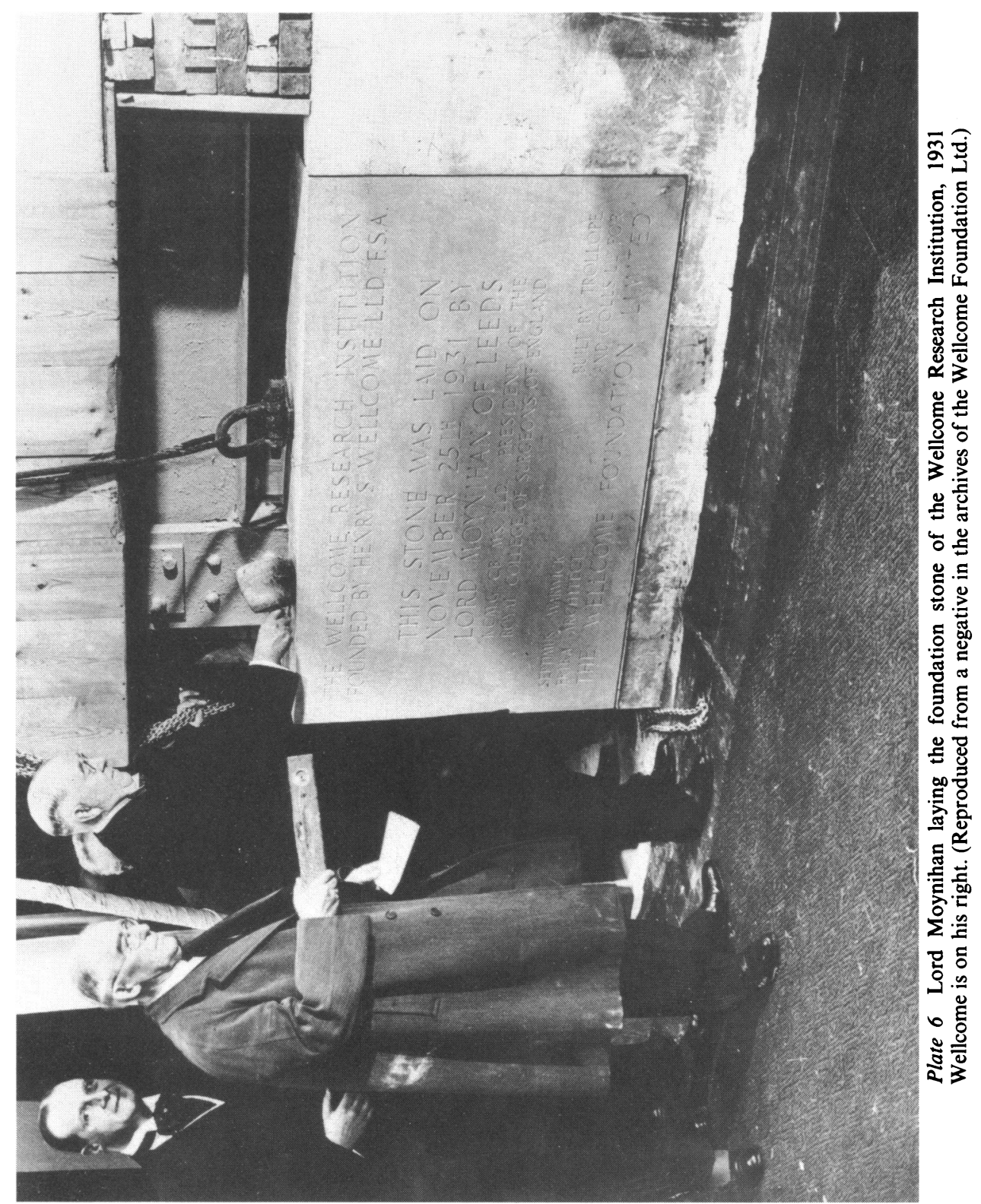


Kulturkreise, or culture circles occupied "museum moles" such as F. Graebner (1877-1934). ${ }^{163}$ In Britain, G. Elliot Smith (1871-1937), Professor of Anatomy at University College from 1919 to 1936, together with his disciple W. J. Perry and, later in his career, W. H. R. Rivers, formed the "triumvirate" of what came to be known as the British diffusionist school. ${ }^{164}$

The "diffusionist" label, however, implied a unity of approach not borne out in practice. Boas was "openly contemptuous" of the British "hyperdiffusionists" and critical of the German approach. It has been argued that both these schools were, in fact, evolutionist (although they denied lawful regularities in history) and both sought grandiose and universal accounts of human history. For the Germans, this lay in a reconciliation with biblical history. From the British school came the theory that almost all sociocultural traits "had been invented once and only once in Egypt". ${ }^{165}$ Boas was not alone in his contempt for the British diffusionists. Elliot Smith led a school to which "virtually everyone else in the world of British anthropology" was hostile. ${ }^{166}$ It was perhaps unfortunate, if not entirely surprising, that almost the only links which the Museum made with academic anthropology were to be with the University College Department of Anatomy. Geographically and, one suspects, ideologically close to Elliot Smith, Wellcome was apparently a frequent enough visitor to feature in an account of a typical day in this Department: "Imagine the callers at Gower Street. At one moment Sir Henry Wellcome wanted Elliot Smith to unwrap a mummy which he had purchased in Eygpt, or a Salvation Army Officer from the West Coast of Africa asked why albinos and twins were drowned at birth by the eugenically-minded natives. At another ... a zealous missionary sought information on polygamy, or a goldminer ... on the association of pearls and cowrie shells."167 Not, as Langham, quoting this passage, points out, the description one might expect of a high-powered research department. Elliot.Smith, trained originally as an anatomist, with no field work to his name, propounded increasingly forcefully, theories which, according to Langham's account, split British anthropology into two camps, with Haddon and the Anthropological Institute on the opposing side. ${ }^{168}$ In 1928, an American critic located Elliot Smith in the "romantic" school of anthropology, which invoked "ill-substantiated hypotheses and invented variegated, 'stranger than fiction' explanations". ${ }^{169}$ Elliot Smith's contribution was assessed by Lowie as "virtually nil". ${ }^{170}$ To Langham, his excursions into diffusionistic ethnology resemble "the outpourings of an over-enthusiastic amateur". ${ }^{171}$

\footnotetext{
${ }^{163}$ Harris, op. cit., note 36 above, pp. 383, 520 .

${ }^{164}$ For detailed descriptions of workers and institutions of the Cambridge and diffusionist schools, centred on Rivers' conversion to diffusionism, see Ian Langham, The building of British social anthropology: W. H. R. Rivers and his Cambridge disciples in the development of kinship studies, 1898-1931. But see Kuklick on this work: essay review 'Ancestor worship', Isis, 1984, 75: 279: 712-717.

165 Harris, op. cit., note 36 above, p. 379.

166 Langham, op. cit., note 164 above, p. 194.

${ }^{167}$ Warren R. Dawson (editor), Sir Grafton Elliot Smith, a biographical record by his colleagues, London, 1938 , p. 178, quoted in Langham, op. cit., note 164 above.

${ }^{168}$ Ibid., pp. 186-187.

169 Ibid., p. 187.

170 Lowie, op. cit., note 36 above, p. 176.

${ }^{171}$ Langham, op. cit., note 164 above, p. 198.
} 
Future anthropological enquiry was to be pursued along very different lines. Anthropologists had moved not only from the armchair to the verandah but into the village. The increasingly influential functionalist and structuralist schools had no place for historical explanation, and little for material culture studies. Neither Bronislaw Malinowski (1884-1942) nor A. R. Radcliffe Browne (1881-1955) made approaches to the Wellcome Historical Medical Museum. ${ }^{172}$ Malinowski had published Argonauts of the Western Pacific in 1922 and increasingly attracted students to the London School of Economics, where a chair of social anthropology was created for him in $1928 .{ }^{173}$ The "structural-functionalist" Durkheimian, Radcliffe-Browne occupied, successively, first chairs in anthropology at Cape Town, Sydney, and, from 1937, Oxford. ${ }^{174}$ Radcliffe-Browne was said to be "opposed to the study of history", and Malinowski, who "thumbed his nose at technology, flouted distribution studies and sneered at reconstruction of the past", vehemently criticized the antiquarianism which he attributed to the search for survivals, and which the Museum must have typified as the end of the twenties approached. ${ }^{175}$ In 1932, as the focus of the discipline moved from museum to university, Wellcome's collections moved into storage, not to reappear until 1947 , by which time approximately sixty per cent had been disposed of. For anthropologists, "the path back to science was to be paved with social structure". ${ }^{176}$ By the late 1930s, the structuralist-functionalist school had gained "virtually unchallenged control of the anthropological establishment throughout the British Empire". 177 "Social anthropologists no longer clutter up their minds with information about skulls and potsherds but look instead to cognate social sciences for stimulus." 178 Wellcome's collection was "cluttered up" with several hundred skulls and several thousand potsherds. They were never to be the subject of the intensive scientific research which he had intended. Singularly unreceptive to the demands of any scientific or historical audience, perhaps because his personal wealth freed him of this constraint, and anxious not to reveal his collection until it was "complete"-a meaningless concept except from the evolutionist viewpoint-Wellcome had delayed too long. Even if the Museum's organizational capacities had coped with the steady flood of acquisitions - which clearly they did not—or had the material been better provenanced, work on pre-existent collections was, by the 1930s, no longer central to anthropological practice in Britain or America.

\footnotetext{
172 On the creation of social anthropology in Britain, and the roles of Malinowski and Radcliffe-Brown, see George W. Stocking jun. (editor), Functionalism historicized, Madison, University of Wisconsin Press, 1984. Malcolm wrote to Malinowski, inviting him to visit the Museum in June 1926. The letter reached Malinowski in California, and he replied that a visit would have to await his return in October. There is no record of it being made. Letters Malcolm/Malinowski, 1 June 1926 and 13 July 1926. WI:Correspondence files, 1926, 'M'.

173 B. Malinowski, Argonauts of the Western Pacific, New York, Dutton, 1922.

174 Raymond Firth, 'Alfred Reginald Radcliffe-Brown, 1881-1955', Proc. Br. Acad, 1956, 42.

175 Harris, op. cit., note 36 above, p. 524. Lowie, op. cit., note 36 above, pp. 234, 5.

${ }^{176}$ Harris, op. cit., note 36 above, p. 523.

177 Ibid., p. 514.

${ }^{178}$ R. Piddington, 'Malinowski's theory of needs' in R. Firth (editor), Man and culture: an evaluation of the work of Bronislaw Malinowski, London, Routledge \& Kegan Paul, 1957, p. 49, quoted in Harris, op. cit., note 36 above, p. 523.
} 


\section{Sir Henry Wellcome's museum for the science of history}

\section{IV}

It is clear that medical historians did not pursue the research which the renegade anthropologists had left undone. Some, such as Arturo Castiglioni (1874-1953), approached the Museum as a source of illustrations (in this case for his History of medicine) and, in 1939, three years after after Wellcome's death, Max Neuburger (1868-1955) was to find refuge in the Museum. ${ }^{179}$ But only a handful of papers directly relating to objects in the collections have ever been published. Prior to 1936, Wellcome's concern with secrecy may have contributed to this state of affairs. It certainly irritated some historians, particularly Charles Singer (1876-1960). (Concurrently with collecting for the Museum, Wellcome was also building up the huge library of the history of medicine that now bears his name. He was content, by and large, to leave its management to the librarian - he did not display the intense interest that he reserved for the museum venture.) Above all a literary historian, and anxious to use the library's resources, Singer was somewhat dismissive of the Museum. "It is no good laying out a lot of instruments and having a sort of Madame Tussaud's show and saying 'This is the History of Medicine" ", he is reported to have said. ${ }^{180}$ The remark, referring to the Museum's use of reconstructed room settings, was perhaps a little unfair, but Singer, one suspects, was not the only physician historian to feel that the Museum's perceptions were rather out of step with his own. Norman Moore (1847-1922), a future President of the Royal College of Physicians, had intimated as much at the opening ceremony of the Historical Medical Exhibition in 1913. Describing the history of medicine as a subject which "divides itself into two great branches", he found these typified by two figures in the Museum. One was the black masked and feathered Mexican God Ixtlilton, the other the Apollo Belvedere. Moore was in no doubt that Apollo, and his son, Asklepios, represented "the true ancestors, the true observing predecessors of Hippocrates and Galen and Avicenna"-and doubtless himself. ${ }^{181}$

This was not merely hubris restricted to men who were fashionable London physicians first and historians second. As the century progressed, historians of medicine of all persuasions were more concerned with the emancipation of medicine from magic. "Folk medicine is a big hodge podge", Henry Sigerist (1891-1957) was to write, allowing, however, that it was "a source which we may have to consult occasionally". $182 \mathrm{He}$ accorded it little value on account of its "total lack of chronology" and saw it rather as recapitulating the entire history of medicine, placing

${ }^{179}$ For Castiglioni's approach, see Report, Malcolm to Wellcome, 6 July 1926. WF:E2:DW. 'WHMM '1926'. On Neuburger, see 'A tribute to Max Neuburger on the occasion of his 75th birthday', Bull. Hist. Med., 1943, 14: 418.

180 Johnston-Saint, Report of a conversation with Singer, 6 January 1927, appended to Report, Malcolm to Wellcome, 21 March 1927. WF:E2:DW. 'WHMM 1927'. On Singer's perception of the history of medicine, see Charles Webster, 'Medicine as social history: changing ideas on doctors and patients in the age of Shakespeare', in L. G. Stevenson (editor), A celebration of medical history, Baltimore and London, Johns Hopkins University Press, 1982.

181 Norman Moore, Opening ceremony of the WHMM, 24 June 1913, printed in the Guide (1927), p. 26-27. Moore was speaking in his capacity as president of the Section of the History of Medicine at the International Congress.

182 Henry Sigerist, A history of medicine, vol 1, New York, Oxford University Press, 1951, pp. 26, 21. 
it at the end, not the beginning, of his projected magnum opus. "The chief source of medical history is literature" he concluded-a view from which subsequent historians have not dissented. ${ }^{183}$ This difference in outlook did not escape Wellcome's notice. Whilst admitting that Norman Moore's address at the 1913 opening had "dealt with the subject in a manner admirable for its type and scope", he anticipated that this would be "very different from the highly scientific type and scope" which Sir Arthur Keith would choose if invited to give the address at the 1926 re-opening. ${ }^{184}$ The contrast between the two views was evident in the Museum's activites throughout the 1910s and 1920s. On its own initiative, the Museum mounted exhibitions such as 'The Folklore of London', or 'Japanese Amulets and Charms' (both in 1916) and commissioned publications dealing with, for example, Celtic medicine. ${ }^{185}$ When initiatives came from the medical profession they were for exhibitions of 'Objects of Shakespearean Interest' or celebrations of the Henry Hill Hickman centenary, and publications such as the one Singer wished to produce on pre-Vesalian dissection. ${ }^{186}$ It would not be surprising if, at a time when the General Medical Council was decorating its new building with bas-reliefs of Ancient Greece, medical men were a little discomfited to find "Adapa, the Sumerian fish deity" illustrated on the frontispiece of the professional diaries they received from Wellcome. ${ }^{187}$ The Museum's friezes and logos, however, from the thumbnail sketch of "Marduk, a Chaldean diety of medicine, about 5000BC", which had accompanied the first circular, to "Phenuka, an Egyptian Priest physician of the Fifth Dynasty", who appeared on the frontispiece of the 1927 Guide, remained, if not prehistoric, very ancient indeed. ${ }^{188}$

Malcolm's appointment in 1925 seems, if anything, to have further entrenched the Museum in Tylorian anthropology of the 1880s. Although trained at the "revolutionary" Cambridge school, Malcolm was apparently not the man to introduce a change of outlook. Pliable, and not particularly innovative, he was content to follow Wellcome's line. His own special interest was apparently physical anthropology, traditionally a conservative area of the discipline, inevitably less affected by social theory or concern over the proper method for field work. ${ }^{189}$ It continued to rely on the

${ }^{183} \mathrm{~F}$. H. Garrison had apparently reached the same conclusion as a result of his visit to the WHMM. “. . . it may be seriously doubted if the essential themes of medical history (as a phase of the history of ideas) can be taught in any museum, even the very best conceivable". See Garrison, op. cit., note 142 above, p. 653.

${ }^{184}$ Letter, Wellcome to Malcolm, 14 August 1926, p. 2. WF:E2:DW. 'WHMM, 1926'.

${ }^{185}$ Special exhibition illustrating the folklore of London consisting of medical charms, amulets, and other objects used to avert disease, to ward-off evil, and to bring good fortune, WHMM, October 1916. Special exhibition of Japanese charms, amulets and objects of medical and other interest, WHMM May 1916. An advance notice of a work on Cymric medicine was printed-History and lore of Cymric medicine, to be issued in the near future, WHMM, 1928-but the publication never appeared. The museum had produced a history of Scottish medicine-John D. Comrie, History of Scottish medicine, London, Baillière, Tindall \& Cox for the Wellcome Historical Medical Museum, 1927.

${ }^{186}$ Exhibition of objects of Shakespearean interest, to illustrate an address on 'Shakespeare as a Guide in the Art and Practice of Medicine' at the Royal Society of Medicine by Sir St. Clair Thomson, WHMM, 27 October 1925. The Hickman centenary celebration was to coincide with a commemoration meeting of the Royal Society of Medicine Section of Anaesthetics. See WF:C2:WE, 'Hickman centenary'. For Singer's suggestion on pre-Vesalian dissection, see his letter to Thompson, 5 January 1921, W. I. Correspondence, 1921 ' $S$ '.

187 The Museum was consulted on possible subjects for these bas-reliefs in 1915. See Report, Thompson to Wellcome, 8 July 1915. WI:FC:9A. For Wellcome's choice of diary illustrations, see Reports, Thompson to Wellcome, 18 and 28 January 1909. WI:FC:9A.

188 Op. cit., note 23 above; and Guide (1927). 


\section{Sir Henry Wellcome's museum for the science of history}

serial arrangement of specimens deriving its methodology largely from comparative anatomy. After his appointment, Malcolm found many areas where "evolutionary series could be completed". ${ }^{190}$ In preparing his outline scheme for the Lister Centenary Exhibition, which the Museum was asked to mount in 1927, he wrote that he had considered the matter both "biometrically and from the empirical point of view". A former pupil of Rivers at Cambridge, was Malcolm trying to apply Rivers' statistical methods to the history of antisepsis? ${ }^{191}$ Further indication of Malcolm's anthropological background can be seen in his remodelling of the Museum's anatomy room, so that the subject was considered almost exclusively from the point of view of representational art, making no reference to the techniques, teaching, or context of anatomists' work. ${ }^{192}$

That museums lagged behind contemporary theory was perhaps an inevitable concomitant of the fact that anthropology was becoming a university rather than a museum-based discipline, and the role of material culture studies diminishing. However, where a close connexion with the academic discipline was maintained, changes had been made to the arrangement of displays-Boas' reorganization of the American Museum of Natural History's ethnographic material is a case in point. ${ }^{193}$ The Wellcome Historical Medical Museum, it seems, never managed to maintain that connexion. It also had little connexion and shared little common ground with any pre-existing "medical" museum. When Osler commented that "nothing like it has ever been put together before", he was essentially accurate. ${ }^{194}$ Of the forty-six "medical museums" known to be in existence in the British Isles in 1913, the year Wellcome opened the Historical Medical Exhibition, only six included any "historical" material, and it is clear that the prime function of all of them was to teach anatomy and gross pathology. ${ }^{195}$ The Royal College of Surgeons had begun a historical collection of instruments in 1910, but this served largely as a repository for those instruments with which the Fellows felt they had contributed notable advances, or which were part of the personalia of eminent surgeons. ${ }^{196}$ The Museum of the Royal College of Surgeons

${ }^{189}$ In the staffing structure which Malcolm proposed for the Museum in 1928 (op. cit., note 95 above) the department he earmarked for himself was 'Physical Anthropology and Racial Development'. See Stocking, op. cit., note 115 above, p. 92 on Rivers' view that the pursuit of physical anthropology (and collection of material culture) actually endangered the rapport necessary for intensive sociological study.

${ }^{190}$ Report, Malcolm to Wellcome. WF:E2:DW. 'WHMM 1927'. On accepting his appointment at the WHMM Malcolm wrote to his previous Director at the Bristol Museum, Herbert Bolton, that "the post ... is really a spot one as far as my particular work is concerned. The work is to be on evolutionary lines throughout, to illustrate the life history of any given cultural element ..... Letter, Malcolm to Bolton, 20 August 1925, City of Bristol Museum and Art Gallery Archives. It seems Malcolm expected that Thompson would "continue his work on the medical collection", presumably leaving Malcolm to develop all the other "cultural elements". See Malcolm to Bolton, 10 October 1925, City of Bristol Museum and Art Gallery Archives.

${ }^{191}$ Letter, Malcolm to Wellcome, 6 July 1926, op. cit., note 64 above, p. 3. WF:E2:DW. 'WHMM, 1926'.

192 For a description of the Anatomy Room, see WHMM Guide (1927), pp. 10-11. "The history of anatomy is illustrated by means of drawings, paintings, and sculpture. From prehistoric days, man has evinced an interest in anatomy, and the earliest delineations of the human body were realistic,..."

${ }^{193}$ See note 161 above.

194 Sir William Osler, visiting the historical medical exhibition prior to the opening in 1913, quoted in Report, Thompson to Wellcome, 27 February 1913. WI:FC:9A.

195 C. J. Hackett, 'A list of medical museums of Great Britain (1949-50)', Br. med. J., 1951, i: 1380-1383.

196 A record of the years from 1901 to 1950. Royal College of Surgeons of England, London, 1951, p. 12. 


\section{Ghislaine M. Skinner}

of Edinburgh had a similar collection, dating from 1883. ${ }^{197}$ The British Museum had acquired between two and three hundred Greek and Roman instruments by 1925, of which an indeterminate number were medical. ${ }^{198}$ Abroad, the Medico-Chirurgical Museum in Ravenna had, since its foundation in the first half of the eighteenth century, collected examples of surgical instrumentation, as well as anatomical specimens, but these were expressly for teaching surgical practice. ${ }^{199}$ The medical museums of Europe were founded largely as adjuncts to the teaching activities of the university medical schools or to commemorate these, or other institutions. ${ }^{200}$ The Museum of the Val-de-Grâce, in Paris, for example, which opened in 1916, two years after Wellcome's Museum, was intended to commemorate "the actions of the French military medical services in the Great War, and to instruct future officers of the Corps de Santé". 201

The Smithsonian Institution in Washington, showing medical exhibits in significant numbers for the first time in 1921, adopted another approach. There, amulets, charms, and tokens were displayed not as indications of the "roots and foundations of things" but "to warn the public against the perils of quackery and the faults of folk medicine ..."202 In 1926, the museum contained exhibits on "how to obtain pure water", "the importance of recreation", and "social, oral and mental hygiene". ${ }^{203}$ This ostensibly historical museum, which certainly owned sizeable historical collections, saw its role in pointing out the evils of the past rather than reconstructing cultural history. In 1929, American medical practice was still, however, a "paradise for quacks", and the Smithsonian Institution had certainly had, during the nineteenth century, a role in evaluating and patenting inventions and innovations not shared by European museums, as Molella has recently pointed out. ${ }^{204}$ However, the title of the gallery in which these medical exhibits were displayed-'The Hall of Health'-is indicative of the rather different tradition to which they belonged. They owed much to the aims of public health educators embodied in the sanitary and hygiene exhibitions held in Europe and the United States from the 1870 s onwards. ${ }^{205}$ In Britain, the most well-known display of this kind was installed at University College as a memorial to Edmund Parkes (1819-76), first Professor of Hygiene at the Military School at

197 William Turner, 'The Public Museums in Edinburgh', Presidential Address, Museums J., 1901-2, $1: 19$.

198 Personal communication, Ralph Jackson, Department of Prehistoric and Romano-British Antiquities, The British Museum.

199 Angelo Francesco La Cava, 'Il piu antico museo medico-chirurgico', Castalia, 1945, 1: $109-114$.

200 The Museum of the Institut für Geschichte der Medizin in Vienna, for example, originated in the 1,192 wax anatomical models provided for teaching purposes by the Emperor Joseph II. It later served, under the direction of Neuburger, to illustrate "the pioneering role of Viennese medicine". Erna Lesky, Das Wiener Institut für Geschichte der Medizin im Josephinum, [n.d.].

201 A. Fabre, Le Val-de-Grâce, Paris, EASSAT, 1975, p. 17.

202 On the history of medical exhibitions at the Smithsonian Institution, see Sami Hamarneh, History of the Division of Medical Sciences in the Museum of History and Technology, Washington, DC, Smithsonian Institution, 1964, Paper 43, Bulletin 240, pp. 271-300.

203 Ibid., p. 278.

204 F. H. Garrison, An introduction to the history of medicine, Philadelphia and London, W. B. Saunders, 1229 , p. 783. A. P. Molella, "At the edge of science: Joseph Henry, "Visionary Theorizers" and the Smithsonian Institution', Ann. Sci., 1984, 41: 5, 445-461.

${ }^{205}$ Bruno Gebhard, 'The changing ideology of health museums and health fairs since 1850', Bull. Hist. Med., 1959, 33: 160-167. 


\section{Sir Henry Wellcome's museum for the science of history}

Chatham, in 1879.206 The Parkes Museum of Hygiene later moved to premises in Margaret Street, under the management of the Royal Sanitary Institute, where it remained until 1909. None of these museums attempted historical exposition of medicine, and none shared the professed aims of the Wellcome Historical Medical Museum.

A more fruitful comparison might be made with the various types of "social museum", as they were sometimes called, which were founded in Europe and North America in the first two decades of this century. ${ }^{207}$ In reports of the new museums, which dealt with transport, religion, sport, childhood pastimes, and so on, it is possible to detect the influence of anthropology. An exhibition of toys, for example, had in its first case a series of toys "illustrating the evolution of the wheel". ${ }^{208}$ In Britain, the founding of such museums was advocated with explicit reference to Pitt-Rivers' sequences of material culture. ${ }^{209}$ That Sir Arthur Keith should, in 1927, advocate Pitt-Rivers as the "patron saint" of museum directors was perhaps not surprising. ${ }^{210}$ These new foundations were indebted to the historical reconstructionism of the anthropologists, owing their very existence to the demonstration that "culture" "evolved". "Museum-making and history-writing are the same thing", said Keith, and would doubtless have agreed with Pitt-Rivers, who in 1874, had defined history as "but another name for evolution". ${ }^{211}$

Medicine, as it had been construed in the natural historical account of some anthropologists, was harder to treat in isolation, than, say, sport or transport, affording for them as it did a demonstration of the "inner history and strivings of mankind and the universal problems of human aspirations". ${ }^{212}$ On the one occasion that the Royal Anthropological Institute met in the Historical Medical Museum, it was perhaps not coincidental that its President that year was J. E. H. Peake (1867-1946), an elderly "museum man", trained originally in archaeology, and that the address was given by Elliot Smith. It was not only anthropologists who were concerned with the "universal problems of human aspirations", said Peake. "The fact is that everybody gets interested in anthropology sooner or later; geologist, businessman, statesman, they all come round to anthropology sooner or later ..."213 He was commenting here on a phenomenon that had largely passed and that had been even more prevalent in the United States, where Spencerian doctrines underlay the Social Darwinism of the

\footnotetext{
206 The Royal Sanitary Institute, Jubilee and London Congress 1926. History of the Institute, compiled by Louis C. Parkes, 1926.

207 Wittlin, op. cit., note 4 above, pp. 172-173.

208 'National Museum of Wales: Exhibition of children's toys, games and playthings', Museums J., 1915-16, 15: 385-388.

${ }^{209}$ See, for example, Balfour, op. cit., note 34 above, pp. 16-17.

${ }^{210}$ Keith, op. cit., note 101 above. Address given at the re-opening ceremony of the W.H.M.M. 1926, printed in WHMM Handbook (1927), p. 104. In this address, Keith briefly considered the extent to which the example of Pitt-Rivers might have influenced Wellcome. Neither the Pitt-Rivers Museum, Oxford, nor the Salisbury and South Wiltshire Museum, has any record of correspondence between Pitt-Rivers and Wellcome (but Pitt-Rivers died in 1900, before Wellcome's major collecting activities had begun).

211 Ibid., p. 103. For Pitt-Rivers' famous conclusion, see Myres (editor), op. cit., note 51 above, p. 24.

212 Elliot Smith, op. cit., note 124 above, p. 2 (Reception).

213 Peake, op. cit., note 124 above, p. 7 (Reception). For biographical details of Peake, see his obituary in the Museums J. 1946-47, 46: 175.
} 
industrial tycoons. ${ }^{214}$ Those who believed in the possibility of a progressive "science of society" gave substantial financial backing to anthropological research. American anthropologists "had educated their millionaires", and, liberally endowed by bodies such as the Rockefeller Foundation and the Carnegie Trust, were the envy of their English colleagues. ${ }^{215}$

However, it has been suggested that the adoption of anthropology as a prescriptive science by United States reformers and politicians at the turn of the century contributed to the depressed state of the discipline there during the 1910s and 1920s. Harris describes a mediocre milieu of amateur theorizers from which only Boas, trained as a physicist, and an immigrant member of an ethnic minority, stood apart. ${ }^{216}$ Returned to his country of origin, Wellcome might have merged perfectly into this milieu-a successful self-made business man, a philanthropist who held commonplace Spencerian views of nature and positivist conceptions of science and found them perfectly blended in a prescriptive "science of history". His involvement with museums had parallels with the activities of the American capitalists. Some of these, like Andrew Carnegie (1835-1919), endowed museums as part of more general and methodical philanthropy. ${ }^{217}$ John Pierpont Morgan (1837-1913), an avid collector of fine art, provided most of the Metropolitan Museum of Art's original collections. ${ }^{218}$ The activities of the motor magnate Henry Ford (1863-1947) bear the most overt similarities to Wellcome's. ${ }^{219}$ Ford became obsessed with salvaging a material culture which, partly due to his own products, was fast vanishing from rural America. He amassed many thousands of artefacts and reconstructed an entire village and an enormous museum to house them. This enterprise he controlled with a personal attention to detail comparable to Wellcome's own. Here, however, the resemblances cease. Ford's museum was concerned entirely with one aspect of material culturetechnology - and, though described as covering the period 1650 to recent times, contained very little material dated earlier than $1830 .{ }^{220}$ Ford displayed none of the concern with primitive origins that so occupied Wellcome, and his museum was a strident hymn to the progress he perceived to have occurred, largely within his own lifetime and only within his own country, through technology. "We have no Egyptian mummies here", said Ford, "for everything we have is strictly American." Guns, steam-engines, and cars jammed the buildings. ${ }^{221}$

\footnotetext{
${ }^{214}$ See R. Hofstadter, Social Darwinism in American thought, 1860-1915, Philadelphia, University of Pennsylvania Press, 1944.

215 Haddon, op. cit., note 112 above, p. 21. Haddon went on to refer to anthropology as "our Cinderella science" (p. 22). See also, Balfour, op. cit., note 38 above, p. 12.

${ }^{216}$ Harris, op cit., note 36 above, p. 253 . "Lacking a firm foundation in the universities, anthropological subjects were still an easy prey for imaginative amateurs."

${ }^{217}$ Dictionary of American biography, New York, Scribners, 1958-1964.

218 Ibid.

219 For a critical account of Ford's museum and the recent redisplay of its Hall of Technology, see Larry Lankton, 'Something old, something new: the re-exhibition of the Henry Ford Museum's Hall of Technology', Technology and Culture, 1980, 21: 594-613. See also, $A$ home for our heritage: The building and growth of Greenfield Village and Henry Ford Museum, 1929-1979, Dearborn Michigan, Henry Ford Museum Press, 1979.

${ }^{220}$ Lankton, op. cit., note 219 above, p. 600.

221 A home for our heritage, op. cit., note 219 above, pp. 11.
} 
Many museums benefited substantially from the activities of American Social Darwinists in the late nineteenth century and subsequently from the trusts and foundations they endowed. ${ }^{222}$ Some, like Pierpont Morgan, gave in kind, but neither Ford nor Wellcome had any intention of bequeathing their collections to the state. ${ }^{223}$ The museum as tangible evidence of evolutionary progress, as a means of interpreting the connexions, whether they were sequences or survivals, between past and present, was unsurpassed. The more or less overtly-stated political aims of Pitt-Rivers in setting up his Farnham museum have recently been examined in this context. ${ }^{224}$ Firm evidence of Wellcome's political views and affiliations must await the detailed examination of archival material not directly related to the Museum. Interestingly, however, the Museum Archives contain a certificate of his election to membership of the American Genetic Association, in $1920 .{ }^{225}$

There remains no comparable venture to the Wellcome Museum of the History of Medicine. Relocated, not in the national ethnographical collections, but in the National Museum of Science and Industry, the re-display of the collections also attempts a comprehensive coverage of the history of medicine. The reconstruction of cultural history, however, is no longer the peculiar province of anthropologists, who increasingly find the "culture concept" itself unsatisfactory. ${ }^{226}$ They are reassessing the place of material culture studies in their discipline, relegated during the decades 1930-70 to studies of technology, "primitive art", and archaeology. A more central role for material culture in anthroplogy since 1970 has been attributed to recent structuralist and Marxist studies. ${ }^{227}$ In museums not specifically devoted to nonliterate cultures, however, the involvement of anthropologists or archaeologists has greatly decreased since they abandoned their claim to a science of universal history. Wellcome's collections, never again under the direction of an anthropologist after

\footnotetext{
${ }^{222}$ See, for example, A record of the public benefactions of Andrew Carnegie, New York, Carnegie Institute, 1919.

${ }^{223}$ See Questionnaire, op. cit., note 114 above, p. 'B'-“'I propose to develop this Museum to be under independent control for all time". Until very recently, Ford's Museum was still administered by a board of trustees controlled by Ford family members. See Lankton, op. cit., note 219 above, p. 595 .

${ }^{224}$ Richard Bradley, 'Archaeology, evolution and the public good: the intellectual development of General Pitt-Rivers', Proceedings of the Summer Meeting of the Royal Archaeological Institute at Weymouth, 1983. Bradley quotes Pitt-Rivers' view that "the law that nature makes no jumps can be taught by the history of mechanical contrivances in such a way as at least to make men cautious how they listen to scatterbrained revolutionary suggestions". A.H.L.F.P. Rivers, 'Typological museums as exemplified by the Pitt-Rivers Museum at Oxford and his provincial museum at Farnham, Dorset', J. Soc. Arts, 1891, 40: 115-122. See also, David K. van Keuren, 'Museums and ideology: Augustus Pitt-Rivers, anthropological museums and social change in late Victorian Britain', Victorian Studies, 1984, 28: 171-189, which deals with similar issues. Both these papers are exceptions to the general lack of interest in the nature of museum display.

${ }^{225}$ Certificate of election of Henry S. Wellcome to membership of the American Genetic Association, 7 May 1920. WF:E2:misc.

${ }^{226}$ Voget, op. cit., note 43 above, p. 381

${ }^{227}$ Miller, op. cit., note 159 above, p. 6. This issue was devoted to an examination of the current role of material culture studies in anthropology. For a reassesment largely from an American point of view, see William N. Fenton, 'The advancement of material culture studies in modern anthropological research', in Miles Richardson (editor), The human mirror. Material and spatial images of man, Baton Rouge, Louisiana State University Press, 1976, pp. 15-36.
} 


\section{Ghislaine M. Skinner}

Malcolm's resignation in 1934, were greatly reduced by those subsequently responsible for them. Not sharing Wellcome's preoccupation with origins, they dispersed many thousands of ethnographic and prehistoric items between 1936 and $1976 .{ }^{228}$ Not sharing his biologized definition of medicine as an extension of the instinct for self-preservation, they dispersed many thousands of objects which seemed more appropriate to other disciplines than the history of medicine. This was in line with a general trend. Material culture in "non-ethnographic", "historical" museums has come to be displayed mainly as an adjunct to, or illustrative of, textual history-an uneasy but largely unprobed relationship. The object sequences of the evolutionist anthropologists, when tied more rigidly to an actual chronology, served to illustrate "whiggish" textual history, and were and are used in this way, particularly in museums of science and technology. They lack meaning, however, in the accounts of more recent historians. In the new Wellcome Museum of the History of Medicine, material culture is used to illustrate the account of modern, textual, historians. Focusing primarily on "society" rather than "man", and attempting to apply the same scrutiny to present and past alike, the anthropological mode of enquiry is simply one amongst several others utilized and has ceased to predominate in the Wellcome Museum. In the new galleries, a section on ethnographic medicine runs neutrally down the centre of an otherwise chronological arrangement, which takes the literate River Valley civilizations as its starting-point. There are no progressive typological sequences of objects, different artefacts from particular periods being grouped together under subject headings, such as 'Paris Medicine', which reflect both an indebtedness to the constructs of modern textual historians and to the more sociological and even anthropological perspective which those historians embrace. No historian would, however, consider, as Wellcome did, that the study of "medicine and its ancillary branches forms an essential section of the science of anthropology", nor that "anthropology takes us from the beginning of the beginning and covers all". 229

\section{ACKNOWLEDGEMENTS}

For reading and commenting on this paper I should like to thank most particularly Christopher Lawrence; also Rosemary Milligan, William Schupbach, and John Symons, and for typing it, Gloria Rodgers.

${ }^{228}$ See Johnston-Saint, op. cit., note 2 above, for details of early sales from the collection.

229 Wellcome, Evidence, op. cit., note 1 above, p. 107. 